\title{
BMP2, 4 and 6 and BMPR1B are altered from early stages of bovine cystic ovarian disease development
}

\author{
Pablo U Díaz ${ }^{1,2, *}$, Gustavo J Hein ${ }^{1,3,}{ }^{*}$, Eduardo M Belotti ${ }^{1,2}$, Fernanda M Rodríguez ${ }^{1}$, \\ Florencia Rey ${ }^{1,2}$, Ayelén N Amweg ${ }^{1}$, Valentina Matiller ${ }^{1,2}$, María E Baravalle ${ }^{1}$, \\ Hugo H Ortega ${ }^{1,2}$ and Natalia R Salvetti ${ }^{1,2}$ \\ 'Instituto de Ciencias Veterinarias del Litoral (ICiVET-Litoral), Universidad Nacional del Litoral - Consejo Nacional \\ de Investigaciones Científicas y Tecnológicas (CONICET), Esperanza, Santa Fe, Argentina, ${ }^{2}$ Facultad de Ciencias \\ Veterinarias, Universidad Nacional del Litoral, Esperanza, Santa Fe, Argentina and ${ }^{3}$ Centro Universitario Gálvez, \\ Universidad Nacional del Litoral, Gálvez, Santa Fe, Argentina
}

Correspondence should be addressed to N R Salvetti; Email: salvetti@fcv.unl.edu.ar

*(P U Díaz and G J Hein contributed equally to this work)

\begin{abstract}
Cystic ovarian disease (COD) is an important cause of subfertility in dairy cattle. Bone morphogenetic proteins (BMPs), mainly BMP2, BMP4 and BMP6, play a key role in female fertility. In this study, we hypothesized that an altered BMP system is associated with ovarian alterations contributing to COD pathogenesis. Therefore, we examined the expression of BMP2, BMP4 and BMP6 and BMP receptor 1B (BMPR1B) in the ovaries of animals with spontaneous or $A C T H$-induced COD, as well as during the development of the disease, in a model of follicular persistence induced by low doses of progesterone (at 5, 10 and 15 days of follicular persistence). Results showed changes in BMP2, BMP4 and BMP6 expression during folliculogenesis, in granulosa and theca cells in the COD groups, as well as at different stages of follicular persistence. Results also showed changes in BMPR1B expression in developing follicles in animals with COD, and at the initial stages of follicular persistence (P5). Comparison between groups showed significant differences, mainly in BMP4 and BMP6 expression, in granulosa and theca cells of different follicular categories. The expression of these BMPs also increased in cystic and persistent follicles, in relation to antral follicles of the control group. BMPR1B showed high expression in cystic follicles. Together, these results may indicate an alteration in BMPs, especially in BMP4 and BMP6, as well as in BMPR1B, which occurs early in folliculogenesis and incipiently during the development of COD, which could be a major cause of recurrence of this disease in cattle.

Free Spanish abstract: A Spanish translation of this abstract is freely available at http://www.reproduction-online.org/content/152/4/333. abstract.

Reproduction (2016) 152 333-350
\end{abstract}

\section{Introduction}

Cystic ovarian disease (COD) is an important cause of subfertility in dairy cattle. This disease has been defined as the presence of cystic structures, in one and sometimes two ovaries, of 17-22 mm diameter, which persist in the absence of luteal tissue, interrupting the normal estrous cycle (Silvia et al. 2002, Peter 2004, Vanholder et al. 2006). Many factors related to management, stress, nutrition and infectious diseases can contribute to the presentation and development of COD in dairy cattle. Although it is accepted that the main component of the ethiopathogenesis of COD is related to a failure in the hypothalamic-pituitary-ovarian axis, there is an intraovarian component that intervenes in the follicular persistence associated with the lack of ovulation (Ortega et al. 2015).

Multiple intraovarian factors participate in the autocrine/paracrine signaling between oocytes, theca cells and granulosa cells, contributing to a coordinated program of follicular cell proliferation and differentiation. In the later stages of follicular development, intraovarian factors modulate the sensitivity of follicular cells to gonadotropins and other hormones (Glister et al. 2010). Locally produced regulatory factors include various members of the transforming growth factor beta (TGFB) superfamily, which includes the bone morphogenetic proteins (BMPs) (Mihm \& Austin 2002, Rossi et al. 2015).

The importance of the BMP system in reproduction has been revealed with the discovery of mutations that 
impair fertility in certain breeds of sheep. Mutations in the Booroola and Inverdale sheep breeds have been attributed to defects in the ovarian BMP system, which lead to an increased ovulation rate (Davis 2005). The Booroola phenotype is caused by a mutation in the BMP receptor 1B (BMPR1B) gene, which results in an increased ovulation rate and multiple births (Souza et al. 2001, Wilson et al. 2001), whereas the Inverdale phenotype arises from a mutation in the BMP15 gene (Galloway et al. 2000), where homozygous inactivating mutations in BMP15 and GDF9 genes impair preantral follicle development, causing sterility (Liao et al. 2003). These results, together with in vitro studies on the effects of BMPs on ovarian cell steroidogenesis (Otsuka et al. 2000, 2001, 2013), point to the BMP system as having a major regulatory role in the mammalian ovary, central to follicular recruitment and selection mechanisms (Glister et al. 2004). In this sense, BMPs play multiple roles in the regulation of growth, differentiation and apoptosis of numerous cell types. Various BMPs have been implicated as autocrine/paracrine regulators of ovarian follicle development (Shimasaki et al. 1999) and are expressed in a cell-specific manner (Shimasaki et al. 2004, Knight \& Glister 2006, Hosoya et al. 2015). In several species, including rats and cattle, BMP4 and BMP7 are expressed mainly in theca cells (Shimasaki et al. 1999, Erickson \& Shimasaki 2003, Glister et al. 2004), BMP2 and BMP6 are expressed in granulosa cells (Erickson \& Shimasaki 2003, Glister et al. 2004, 2010) and BMP6 and BMP15 are expressed in oocytes (Erickson \& Shimasaki 2003, Glister et al. 2004, 2005).

Like other members of the TGFB superfamily, BMPs are dimeric proteins that interact with target cells by forming hetero-oligomeric complexes with two types of serine/threonine kinase receptors (type 1 and type 2) located on the cell surface (Glister et al. 2005). Transphosphorylation of type 1 receptor by complexed type 2 receptor leads to phosphorylation of intracellular signaling intermediaries called SMADs 1, 5 or 8 , which associate with co-SMAD4 before translocating to the nucleus to alter gene transcription (Glister et al. 2005).

The participation of the BMP system in the regulation of ovarian function has been extensively established in many species, including rats and cattle (Glister et al. 2010, Hosoya et al. 2015). BMPs, mainly BMP2, BMP4, BMP6 and BMP7, play a key role in female fertility by regulating steroidogenesis and mitosis in granulosa cells (Otsuka 2013). In particular, BMP ligands commonly inhibit follicle-stimulating hormone (FSH)-induced progesterone synthesis (Shimasaki et al. 1999, 2004, Erickson \& Shimasaki 2003, Inagaki et al. 2009, Otsuka et al. 2011, Hosoya et al. 2015). This inhibition suggests a key role of BMPs as luteinization inhibitors (Otsuka et al. 2000, 2001). Treatment with BMP4, BMP6 and BMP7 increases basal and insulin-like growth factor 1 (IGF1)-induced estradiol production by bovine granulosa cells in vitro (Glister et al. 2004) and decreases forskolin-induced progesterone production in luteinized bovine granulosa cells in vitro (Kayani et al. 2009). Similarly, BMP2, added to sheep granulosa cell cultures, results in enhanced estradiol production (Souza et al. 2002). Moreover, BMP4 and BMP7 inhibit granulosa cell apoptosis (Shimizu et al. 2012). The importance of this finding is highlighted by the fact that the control of follicular cell proliferation is crucial for follicle dominance and atresia (Erickson \& Shimasaki 2003).

Considering the importance of the BMP system in follicle growth, we hypothesized that an altered BMP system is associated with ovarian alterations such as follicular persistence and thus contributes to COD pathogenesis. Therefore, in this study, we examined the immunolocalization and expression of the most important BMPs (BMP2, BMP4 and BMP6), which are produced by somatic follicular cells, and BMPR1B in the ovaries of healthy cows and animals with spontaneous or adrenocorticotropic hormone (ACTH)-induced COD. In addition, we evaluated the expression of these important proteins in an experimental model of follicular persistence induced by low levels of progesterone to establish incipient changes during COD development that could contribute to its pathogenesis.

\section{Materials and methods}

\section{Induction and detection of COD and follicular persistence}

All procedures were evaluated and approved by the Ethics and Security Committee of the Facultad de Ciencias Veterinarias of the Universidad Nacional del Litoral, Santa Fe, Argentina (protocol numbers: 44/10; 131/12), and are consistent with the Guide for the Care and Use of Agricultural Animals in Research and Teaching (Federation of Animal Science Societies, 2010).

\section{Induction of COD by ACTH administration}

Ten Argentinean Holstein heifers with regular estrous cycles were used. The stages of the estrous cycles were synchronized using the Ovsynch protocol: the animals were injected with a gonadotropin-releasing hormone (GNRH) analog (buserelin acetate, $10 \mu \mathrm{g} / \mathrm{animal}$, Gonaxal, BiogénesisBagó, Buenos Aires, Argentina) on day 9, a prostaglandin $\mathrm{F}_{2 \alpha}$ analog (D+cloprostenol, $150 \mu \mathrm{g} /$ animal, Enzaprost D-C, Biogénesis-Bagó, Argentina) on day 2 and a GNRH analog (buserelin acetate, $10 \mu \mathrm{g} / \mathrm{animal}$, Gonaxal; Biogénesis-Bagó, Buenos Aires, Argentina) on day 0. The time of ovulation was monitored by transrectal ultrasonography and designated as day 1 of the estrous cycle because ovulation occurs 24-32 h after the second injection of GNRH (Pursley et al. 1995).

The model of ACTH-induced ovarian follicular cysts used in this study has been described and characterized previously (Dobson et al. 2000, Ortega et al. 2008, Salvetti et al. 2010, Amweg et al. 2013). Briefly, beginning on day 15 of a synchronized estrous cycle, five heifers received subcutaneous 
injections of $1 \mathrm{mg}$ of a synthetic polypeptide with ACTH activity (Synacthen Depot, Novartis, Basel, Switzerland) every $12 \mathrm{~h}$ for 7 days (ACTH-treated group). The other five animals received $1 \mathrm{~mL}$ saline solution (control group).

Ovarian ultrasonography was performed in all animals, using a real-time, B-mode scanner equipped with a $5-\mathrm{MHz}$, linear array, transrectal transducer (Honda HS101V, Japan) (Sirois \& Fortune 1988). The growth and regression of follicles $>5 \mathrm{~mm}$, corpora lutea and follicular cysts were monitored. Daily ovarian ultrasonography was performed throughout a complete estrous cycle in control heifers (21-23 days) and from day 14 (day 1 =day of ovulation) until ovariectomy approximately on day 48 in ACTH-treated heifers. Follicular cysts detected by ultrasonography were defined as follicular structures with a diameter equal to or greater than $20 \mathrm{~mm}$, present for 10 days or more, without ovulation or corpus luteum formation (Dobson et al. 2000, Ortega et al. 2015). The first day of follicular cyst formation was the day a follicle attained $20 \mathrm{~mm}$ or more in diameter and the ovaries were removed 10 days later by ovariectomy (approximately day 48). In the control heifers, ovariectomy was conducted when the dominant follicle reached a diameter greater than $10 \mathrm{~mm}$, in the absence of an active corpus luteum, to obtain preovulatory follicles (approximately day 18). Blood samples were obtained daily throughout the experiment to test hormone levels.

Successful induction of ACTH-induced COD was confirmed by ovarian morphology and hormone concentrations. In ACTH-treated animals, healthy developing follicles, follicles with different degrees of atresia and one large follicular cyst (in one ovary) with a complete granulosa cell layer were observed. Active luteal tissue was absent in all cases. Ovaries from control animals exhibited follicles at various stages of development, including primordial, transition, primary, small and large preantral and small and large antral follicles, as well as atretic follicles and regressed corpora lutea. These data have been published previously (Ortega et al. 2008, Amweg et al. 2013).

\section{Spontaneous COD}

Argentinean Holstein cows from dairy herds of the milkproducing region of Santa Fe, Argentina, were used. Cows with spontaneous COD were used to obtain whole ovaries by ovariectomy or follicular fluid (FF) by follicular aspiration. Animals were diagnosed with COD during the periodic reproductive control by rectal palpation and confirmed by ultrasonography, considering parameters described previously (Silvia et al. 2002, Bartolome et al. 2005). As control animals, reproductively healthy cows with regular estrous cycles were synchronized as described previously, by the Ovsynch protocol to obtain samples at proestrus of ovaries or FF.

Ovariectomy: It was conducted when the veterinarian responsible for the reproductive health of animals indicated castration to prolong lactation until shipment to killing (Yart et al. 2012). The ovaries from control cows $(n=5)$ and cows with spontaneous COD $(n=10)$ were removed by ovariectomy and blood samples were collected just before surgery for hormone analysis (Marelli et al. 2014). These ovaries were intended for analysis of protein expression by immunohistochemistry and Western blotting. Small samples from ovarian tissues of each group were immediately frozen at $-80^{\circ} \mathrm{C}$ until their use in Western blotting to determine the specificity of the antibodies used in immunohistochemistry.

FF aspiration: Additionally, FF samples from control cows $(n=10)$ and cows with spontaneous COD $(n=15)$ were aspirated using a digital ultrasound system Chison 8300 Vet equipped with a micro-convex transducer of $5.0 \mathrm{MHz}$ mounted on a transvaginal probe for follicular aspiration (Watanabe Applied Technology Limited, Brazil). The FF was transported to the laboratory refrigerated on ice and then centrifuged for $10 \mathrm{~min}$ at $2700 \mathrm{~g}$ to obtain cell pellets and pure FF, which were stored at $-80^{\circ} \mathrm{C}$. These cells were destined to mRNA analysis.

The health status of the follicles was confirmed by hormonal concentrations in FF. The levels of $17 \beta$-estradiol, progesterone and testosterone in FF were measured by ELISA kits (Estradiol EIA, DSL-10-4300; Progesterone EIA, DSL-10-3900; Testosterone EIA, DSL-10-4000; Diagnostic Systems Laboratories, Webster, TX, USA) according to the manufacturers' instructions. The assay sensitivity was $7 \mathrm{pg} / \mathrm{mL}$ for $17 \beta$-estradiol, $0.13 \mathrm{ng} / \mathrm{mL}$ for progesterone and $0.04 \mathrm{ng} / \mathrm{mL}$ for testosterone. Intra-assay coefficients of variation were 9.3, 8.2 and $11.4 \%$ respectively and inter-assay coefficients of variation were $7.5,6.8$ and $11.9 \%$ respectively.

\section{Induction of follicular persistence by progesterone administration}

This model was performed in nonlactating Holstein cows $(n=20)$ with regular estrous cycles. Ovarian activity was synchronized starting with the procedure commonly referred to as G6G (Pursley et al. 1995, Bello 2006, Díaz et al. 2015) with some modification, and only cows with one or more corpora lutea identified by transrectal ovarian ultrasonography were selected. The synchronization protocol consisted of two doses of prostaglandin F2 $\alpha$ (PGF2 $\alpha ; 150 \mu \mathrm{g}$ D+cloprostenol; Enzaprost DC, Biogénesis-Bagó, Garín, Buenos Aires, Argentina) administered $12 \mathrm{~h}$ apart on day 0 to induce luteolysis (Hatler et al. 2008), followed by a dose of GNRH $(20 \mu \mathrm{g}$ buserelin acetate; Gonaxal, BiogénesisBagó, Argentina) 2 days later to stimulate ovulation of the preovulatory follicles present. After 6 days of the first GNRH dose, the cows started the Ovsynch protocol with another injection of GNRH. After 7 days, cows received two doses of PGF2 $\alpha, 12 \mathrm{~h}$ apart, to ensure luteolysis (completion of the modified synchronization protocol).

After synchronization, cows were divided into four groups: the control group $(n=5)$ and groups P5 (5 days of follicular persistence; $n=5$ ), P10 (10 days of follicular persistence; $n=5$ ) and P15 ( 15 days of follicular persistence; $n=5$ ). Control cows did not receive any additional hormonal treatment. On day 16 after estrus synchronization, cows of groups P5, P10 and P15 were treated with an intravaginal progesterone device (750 mg micronized progesterone; Pro-Ciclar P4-Zoovet, Santa Fe, Argentina) inserted 1 day after the first PGF2 $\alpha$ injection of Ovsynch to obtain subluteal concentrations of progesterone $(1-2 \mathrm{ng} / \mathrm{mL})$, as described by Bigelow \& Fortune (1998) and Díaz et al. (2015). On an average, ovulation occurred around 4 days after administration of the first PGF2 $\alpha$ dose (range 101-106h). This device was kept in the cows for 5 days after expected ovulation in group P5 and for 8 days 
in groups $\mathrm{P} 10$ and $\mathrm{P} 15$. In the latter two groups (P10 and $\mathrm{P} 15)$, a new intravaginal progesterone-releasing device was introduced 1 day before removal of the first one to maintain a more consistent concentration of progesterone throughout the treatment period. In group P15, a third intravaginal progesterone-releasing device was introduced on day 11 of persistence, 1 day before removal of the second one (Fig. 1) (for more details, see Díaz et al. 2015).

Bilateral ovariectomy was performed in control cows, 2 days after completion of the synchronization protocol ( $48 \mathrm{~h}$ after the first PGF2 $\alpha$ injection of Ovsynch) and on days 5, 10 and 15 of follicular persistence in groups P5, P10 and P15 respectively (Marelli et al. 2014, Díaz et al. 2015). Blood samples were obtained daily throughout the experiment to test hormone levels (Díaz et al. 2015).

Successful induction of progesterone-induced follicular persistence was confirmed by ovarian morphology and hormone concentrations (Díaz et al. 2015). Ovaries from groups P5, P10 and P15 presented all stages of follicular growth and development, including primordial, small preantral, large preantral and antral follicles, follicles showing different degrees of atresia and a single large persistent follicle. Corpora lutea were absent in all cases. All persistent follicles had a complete granulosa, an intensely vascularized theca interna and a collagenous theca externa layer. Ovaries from control animals exhibited follicles at various stages of development, including, primary, small and large preantral and antral follicles, as well as atretic follicles and regressed corpora lutea.

\section{Tissue sampling and follicle classification}

For immunohistochemistry, the ovaries obtained by ovariectomy from animals with ACTH-induced COD, spontaneous COD, progesterone-induced follicular persistence and control animals were fixed in $4 \%$ buffered formaldehyde for $8-10 \mathrm{~h}$ at $25^{\circ} \mathrm{C}$ and then washed in phosphate-buffered saline (PBS). Then, fixed tissues were dehydrated in an ascending series of ethanol, cleared in xylene and embedded in paraffin. Sections ( $5 \mu \mathrm{m}$ thick) were mounted on slides treated previously with $2 \%$ $(\mathrm{v} / \mathrm{v})$ 3-aminopropyltriethoxysilane in acetone (Sigma-Aldrich) and primarily stained with hematoxylin-eosin for preliminary observation of the ovarian structures (Salvetti et al. 2010). Follicles were classified into the following groups: primordial, transition, primary, small preantral, large preantral, small antral, large antral and atretic follicles (Braw-Tal \& Yossefi 1997); follicular cysts (Silvia et al. 2002); and persistent follicles (Díaz et al. 2015). Only follicular cysts without luteinization and with a complete granulosa cell layer were analyzed.

For real-time polymerase chain reaction (RT-PCR) analysis, the pellet of follicular cells was obtained from FF aspirate of large antral follicles $>10 \mathrm{~mm}$ in diameter from control animals (Parrott \& Skinner 1997) and spontaneous follicular cysts $\geq 20 \mathrm{~mm}$ (Silvia et al. 2002). To classify the antral follicles destined to mRNA analysis, steroid concentrations were measured in FF. Only large antral follicles categorized as estrogen-active ( $17 \beta$-estradiol: progesterone ratio $>1$ ) and nonatretic (17 $\beta$-estradiol:testosterone ratio $>1)$ were used. There were no differences in $17 \beta$-estradiol concentrations between cystic $(217.30 \pm 42.12 \mathrm{ng} / \mathrm{mL})$ and large antral follicles $(281.20 \pm 21.04 \mathrm{ng} / \mathrm{mL})$. The mean progesterone concentration was significantly higher in the FF of large antral follicles $(57.06 \pm 3.30 \mathrm{ng} / \mathrm{mL})$ than in that of cystic follicles $(33.91 \pm 2.76 \mathrm{ng} / \mathrm{mL})$.

\section{Analysis of $m R N A$ expression of BMP2, BMP4 and BMP6}

\section{RNA purification}

Total RNA was isolated from the follicular cell pellet of estrogenactive antral follicles from the control group and cystic follicles from the spontaneous COD group, after treatment with TRIzol LS reagent (Invitrogen, Life Technology), according to the manufacturer's instructions (Marelli et al. 2014).

\section{Reverse transcription}

To avoid genomic DNA contamination, RNA samples were treated with DNAse (Invitrogen) according to the manufacturer's instructions. First-strand cDNA was synthesized using a master mix containing Moloney

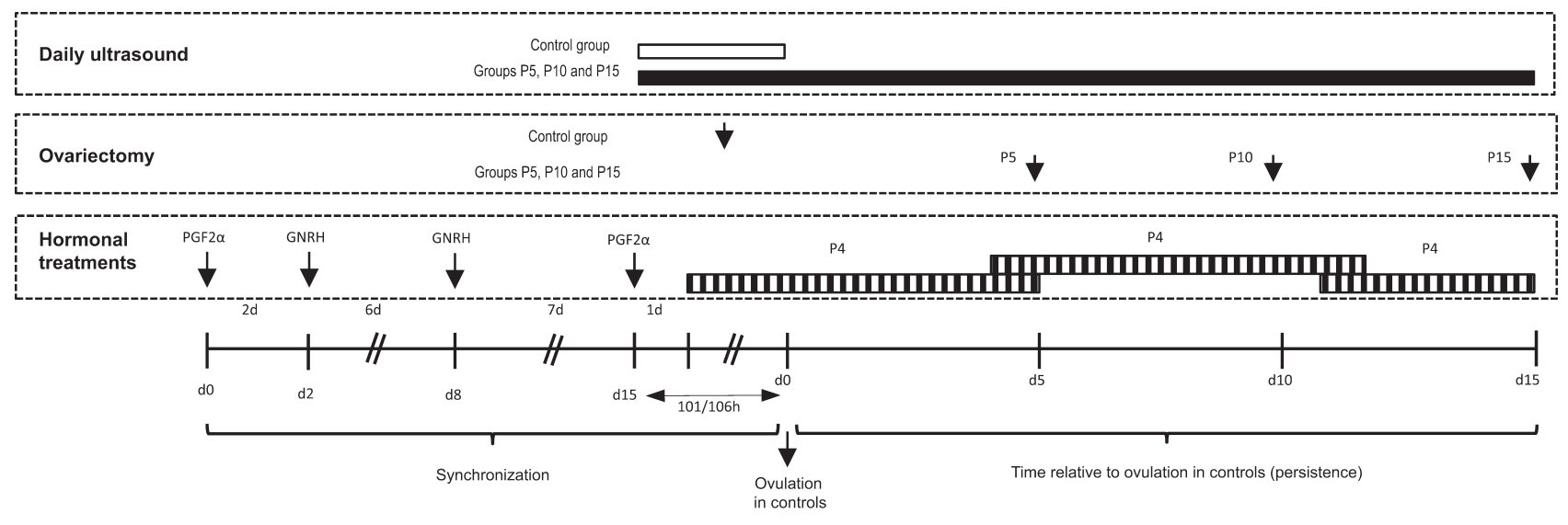

Figure 1 Experimental design for the induction of follicular persistence by progesterone. Holstein cows were synchronized and received an intravaginal progesterone-releasing device to induce follicular persistence. Follicular dynamics were followed by daily ultrasound scanning as indicated. Ovariectomy was performed in proestrus (controls) and after 5, 10 and 15 days of follicular persistence. 
Murine Leukemia Virus (MMLV) buffer, dithiothreitol (DTT), RNAout, MMLV reverse transcriptase, deoxyribonucleotide triphosphate (dNTP) and random primers (Invitrogen). The reverse transcription conditions consisted of $10 \mathrm{~min}$ of annealing at $25^{\circ} \mathrm{C}, 50 \mathrm{~min}$ of cDNA synthesis at $37^{\circ} \mathrm{C}$ and 15 min of DNAse inactivation at $70^{\circ} \mathrm{C}$.

\section{Real-time PCR}

Cytochrome P450 aromatase (CYP19a1) and cytochrome P450 17 hydroxylase/17,20-lyase (CYP17a1) sequences were amplified to confirm bovine granulosa and theca cell mRNA in all samples using the primers described by Lagaly et al. (2008) from Invitrogen, Life Technology (Table 1). Follicular cell samples obtained by follicular aspiration were positive for CYP19A1 mRNA and/or CYP17A1 mRNA, confirming the presence of granulosa and/or theca cells in the samples (data not shown). We analyzed only samples from spontaneous cysts and control antral follicles that were positive for CYP17a1 and CYP19a1 (granulosa and theca cells). Samples with both populations (granulosa and theca cells) were selected because the method to obtain samples (ultrasoundguided aspiration) did not allow us to obtain samples of granulosa only.

An optimized RT-PCR protocol was used to analyze the mRNA expression of BMP2, BMP4 and BMP6, using SYBR Green I technology (Invitrogen) (Pfaffl 2001). The relative amount of mRNA of the BMPs was normalized to a constant amount of $\beta$-actin mRNA as a reference gene (Robinson et al. 2007). PCR was performed by using defined concentrations of specific forward/reverse primers detailed in Table 1. Primers and amplification products were verified in silico using Basic Local Alignment Search Tool (BLAST; http://www.ncbi.nlm. nih.gov/BLAST) to confirm gene specificity.

Each PCR was performed in duplicate in a total volume of $20 \mu \mathrm{L}$ containing $4 \mu \mathrm{L}$ cDNA $(500 \mathrm{ng} / \mathrm{mL}), 4 \mu \mathrm{L} 5 \mathrm{X}$ Phire reaction buffer, $0.5 \mu \mathrm{L}$ of each $10 \mu \mathrm{M}$ forward/reverse primer, $0.2 \mathrm{mM} d \mathrm{NTPs}, 1 \mu \mathrm{L}$ SYBR Green I (Invitrogen), $0.05 \mu \mathrm{L}$ Phire
Taq polymerase (Thermo Fisher Scientific) and $14 \mu \mathrm{L}$ sterilized DEPC-treated water.

Transcript levels were estimated by relative quantitative RT-PCR using the StepOne Real-Time PCR System (Applied Biosystems). Thermal cycling conditions included 40 cycles of denaturation at $98^{\circ} \mathrm{C}$ for $5 \mathrm{~s}$; annealing at $61^{\circ} \mathrm{C}(\mathrm{BMP} 2)$, $58^{\circ} \mathrm{C}$ (BMP4 and BMP6) and $60^{\circ} \mathrm{C}$ ( $\beta$-actin) for $20 \mathrm{~s}$; and extension at $72^{\circ} \mathrm{C}$ for $20 \mathrm{~s}$. A single initial denaturation step at $98^{\circ} \mathrm{C}$ for $3 \mathrm{~min}$ and a final extension step at $72^{\circ} \mathrm{C}$ for $20 \mathrm{~s}$ were performed.

Efficiency of PCRs and relative quantities were determined from a six-point standard curve. Standard curves were constructed from a dilution series of pooled cDNAs and PCR efficiency was calculated using the StepOne v2.2 software (Applied Biosystems).

The mRNA expression levels of genes were recorded as a cycle threshold $(\mathrm{Ct})$ value that corresponded to the number of cycles at which fluorescence signal was detected above a threshold value and was calculated using StepOne v2.2. Negative DNA template controls were included in all assays. Product purity was established by dissociation curves, and random samples were subjected to agarose gel electrophoresis to verify the product sizes. To validate the PCR conditions, standard curves prepared with serial dilutions of complete follicular wall cDNAs were obtained for BMP2, BMP4, BMP6 and $\beta$-actin. These curves give valuable information about the range of template concentrations that yield similar amplification efficiency. The PCRs presented efficiencies of $100.9 \%$ for BMP2, 99.2\% for BMP4, 94.6\% for BMP6 and $93.44 \%$ for $\beta$-actin. In all cases, the amplification reactions presented high linearity with a $R^{2}>0.99$. The absence of nonspecific PCR products and primer-dimer artifacts was checked by melting curve analysis.

\section{Nucleotide sequencing}

The specificity of the PCR products was confirmed by DNA sequencing by using the Macrogen Sequencing Service

Table 1 Primer pairs (forward and reverse primer sequences, $5^{\prime} \rightarrow 3^{\prime}$ ) used for real-time PCR.

\begin{tabular}{|c|c|c|c|c|c|}
\hline Name & Sequence $\left(5^{\prime}-3^{\prime}\right)$ & Gene accession no. & $\begin{array}{l}\text { Amplicon size } \\
\text { (bp) }\end{array}$ & $\begin{array}{l}\text { Annealing temperature } \\
\qquad\left({ }^{\circ} \mathrm{C}\right)\end{array}$ & Reference \\
\hline \multicolumn{6}{|l|}{ BMP2 } \\
\hline $\begin{array}{l}\text { Forward } \\
\text { Reverse }\end{array}$ & $\begin{array}{l}\text { TGTCCAAACTСTGGTCAACTC } \\
\text { CTCGACAACСАTGTCСTGATAG }\end{array}$ & NM_001099141 & 142 & 61.0 & This study \\
\hline \multicolumn{6}{|c|}{ 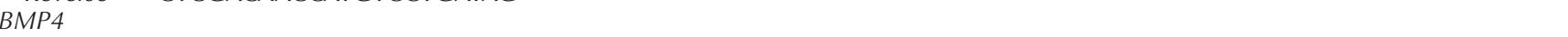 } \\
\hline $\begin{array}{l}\text { Forward } \\
\text { Reverse }\end{array}$ & $\begin{array}{l}\text { GGCCGACСАССТСААСТСАА } \\
\text { АСАТСССТССАСТАССАТСТССТG }\end{array}$ & NM_001045877 & 181 & 58.0 & This study \\
\hline \multicolumn{6}{|c|}{ the } \\
\hline $\begin{array}{l}\text { Forward } \\
\text { Reverse }\end{array}$ & $\begin{array}{l}\text { CGCCAGCGACACCACAAAGAGT } \\
\text { CCCAGCAGAAACAGGTCCGAGTC }\end{array}$ & XM_005192966 & 191 & 58.0 & This study \\
\hline \multicolumn{6}{|c|}{ (2) } \\
\hline $\begin{array}{l}\text { Forward } \\
\text { Reverse }\end{array}$ & $\begin{array}{l}\text { GGAGGCGACCATCAGAGAAGTGC } \\
\text { CAGCCGGGACATGAAGAGGAAGAG }\end{array}$ & NM_174304 & 319 & 60.8 & Lagaly et al. (2008) \\
\hline \multicolumn{6}{|c|}{ (6) } \\
\hline Forward & TAAAACAAAGCGCCAATCTCTACG & U18447 & 341 & 55.4 & Lagaly et al. (2008) \\
\hline \multicolumn{6}{|c|}{ ( } \\
\hline Forward & CGGAACCGCTCATTGCC & ВТ030480 & 290 & 60 & Riollet et al. (2001) \\
\hline Reverse & ACCCACACTGTGCCCATCTA & & & & \\
\hline
\end{tabular}


(Macrogen, Korea). Oligonucleotide primers and amplification products were then tested using BLAST (http://www.ncbi.nlm. nih.gov/BLAST) to confirm gene specificity and to determine nucleotide locations, making sure that they were not designed from any homologous regions coding for other genes. The identity of the PCR products was confirmed (range 97-99\% homology with bovine reference sequences). No differences were detected in $\beta$-actin gene expression between the different groups evaluated $(P>0.05)$.

\section{Immunohistochemistry}

The details, suppliers and concentrations of the antibodies used are presented in Table 2. Each antibody was assayed in at least five sections of each ovary from each animal. A total of approximately 15 sections from each animal were taken for immunohistochemical quantification. A streptavidin-biotin immunoperoxidase method was performed as described previously (Matiller et al. 2014). Briefly, after deparaffinization, microwave pretreatment (antigen retrieval) was performed by incubating the sections in $0.01 \mathrm{M}$ citrate buffer ( $\mathrm{pH}$ 6.0) except for BMP4 (Table 2). Endogenous peroxidase activity was inhibited with $3 \%(\mathrm{v} / \mathrm{v}) \mathrm{H}_{2} \mathrm{O}_{2}$ in methanol, and nonspecific binding was blocked with $10 \%(\mathrm{v} / \mathrm{v})$ normal goat serum in PBS. All sections were incubated with the primary antibodies for $18 \mathrm{~h}$ at $4^{\circ} \mathrm{C}$ and then for $30 \mathrm{~min}$ at room temperature with biotinylated secondary antibodies (CytoScan HRP Detection System; Cell Marque, Rocklin, CA, USA). The antigens were visualized by the CytoScan HRP Detection System, and 3.3-diaminobenzidine (DAB Liquid DAB-Plus Substrate Kit; Invitrogen) was used as the chromogen. Finally, the slides were washed in distilled water and counterstained with Mayer's hematoxylin, dehydrated and mounted.

To verify immunoreaction specificity, adjacent control sections were subjected to the same immunohistochemical method, replacing primary antibodies with rabbit and mouse nonimmune sera. The specificity of the secondary antibodies was tested by incubation with primary antibodies with negative reaction to bovine antigens: anti-human CD45 (clone: PD7/26; Dako) and anti-human estrogen receptor alpha (polyclonal, Cell Marque). To exclude the possibility of nonsuppressed endogenous peroxidase activity, some sections were incubated with DAB alone.

\section{Western blotting}

To test the specificity of the antibodies used, complete walls of tertiary follicles and follicular cysts were homogenized in a radioimmunoprecipitation assay (RIPA) lysis buffer consisting of $1 \% \mathrm{v} / \mathrm{v}$ IGEPAL CA630 (octylphenyl-polyethylene glycol), $0.5 \%$ sodium deoxycholate, $0.1 \%$ SDS, $1 \mathrm{mM}$ EDTA, $50 \mathrm{mM}$ sodium fluoride (all from Sigma-Aldrich), 0.1M PBS and a protease inhibitor cocktail (Complete Mini Protease Inhibitor Cocktail Tablets; Roche). Follicle homogenates were centrifuged at $14,000 \mathrm{~g}$ for $20 \mathrm{~min}$ and the supernatant was stored frozen at $-80^{\circ} \mathrm{C}$. Proteins $(40 \mu \mathrm{g})$ were separated by sodium dodecyl sulfate polyacrylamide gel electrophoresis (SDS-PAGE) (15\% resolving gel) under reducing conditions, transferred onto nitrocellulose membranes (GE Healthcare), blocked for $5 \mathrm{~h}$ in $5 \%$ nonfat milk in tris-buffered saline containing 0.05\% Tween 20 (Sigma-Aldrich), and then incubated overnight at $4{ }^{\circ} \mathrm{C}$ with specific primary antibodies (Table 1). Following washing, membranes were treated with the corresponding secondary peroxidase-conjugated antibody for $1 \mathrm{~h}$ (Table 2). The immunopositive bands were detected by chemiluminescence, using the ECL-plus system (GE Healthcare) on hyperfilm-ECL film (GE Healthcare).

Western blotting analysis detected intense positive bands of appropriate sizes for each of the molecules studied by immunohistochemistry. BMP2 was detected as a single band at 30-38 kDa, BMP4 as a double band at 42-47 kDa, BMP6 as a single band at $55 \mathrm{kDa}$ and BMPR1B as a single band at $50 \mathrm{kDa}$.

\section{Image analysis}

Images were analyzed using Image Pro Plus 3.0.1 (Media Cybernetics, Silver Spring, MA, USA). For immunohistochemistry, images were digitized using a CCD color video camera (Motic 2000; Motic China Group, China) mounted on a conventional light microscope (Olympus $\mathrm{BH}-2$; Olympus) and using an objective magnification of $\times 40$. The microscope was prepared for Koehler illumination. This was achieved by recording a reference image of an empty field for the correction of unequal illumination (shading correction) and calibrating the measurement system with a reference slide to determine background threshold values. The reference slides contained a series of tissue sections in which the primary

Table 2 Antibodies, suppliers, conditions and dilutions used for immunohistochemistry (IHC) and Western blot (WB).

\begin{tabular}{|c|c|c|c|c|}
\hline \multirow[b]{2}{*}{ Antibodies } & \multirow[b]{2}{*}{ Source } & \multirow[b]{2}{*}{ Conditions for IHC } & \multicolumn{2}{|c|}{ Antibody dilution } \\
\hline & & & $\mathrm{IHC}$ & $W B$ \\
\hline \multicolumn{5}{|l|}{ Primary antibodies } \\
\hline BMP2 & Mouse monoclonal, ab6285 (Abcam) & Antigen retrieval with citrate buffer in MW & $1: 75$ & $1: 75$ \\
\hline BMP4 & Rabbit polyclonal, ab 39973 (Abcam) & Without antigen retrieval. & $1: 350$ & $1: 350$ \\
\hline BMP6 & Mouse monoclonal, ab15640 (Abcam) & Antigen retrieval with citrate buffer in $\mathrm{MW}$ & $1: 150$ & $1: 150$ \\
\hline BMPR1B & $\begin{array}{l}\text { Rabbit polyclonal, sc25455 (Santa Cruz } \\
\text { Biotechnology) }\end{array}$ & Antigen retrieval with citrate buffer in $\mathrm{MW}$ & $1: 500$ & $1: 500$ \\
\hline \multicolumn{5}{|l|}{ Secondary antibodies } \\
\hline Biotinylated link & $\begin{array}{l}\text { CytoScan Biotinylated Link, CytoScan HRP } \\
\text { Detection System (Cell Marque, Rocklin, } \\
\text { CA, USA) }\end{array}$ & & Ready to use & - \\
\hline HRP-anti-mouse IgG & $\begin{array}{l}\text { Goat Polyclonal. sc-2005 (Santa Cruz } \\
\text { Biotechnology) }\end{array}$ & & - & $1: 2000$ \\
\hline HRP-anti-rabbit IgG & $\begin{array}{l}\text { Goat Polyclonal. sc-2004 (Santa Cruz } \\
\text { Biotechnology) }\end{array}$ & & - & $1: 2000$ \\
\hline
\end{tabular}


antibodies were replaced with rabbit and mouse nonimmune sera. The positive controls were used as inter-assay controls to maximize the levels of accuracy and robustness of the method (Ranefall et al. 1998). The slides were scanned left to right from the top and all follicles in the selected categories (between 8 and 15 in the sections evaluated) were analyzed. The image analysis score was calculated separately in each follicular wall layer (granulosa and theca interna) from at least 50 images of the different categories of follicles from ovaries of all groups.

The percentage of the immunohistochemically stained area was calculated as a percentage of the total area evaluated through the color segmentation analysis, which extracts objects by locating all objects of the specific color (brown stain). The methodological details of image analysis as a valid method for quantification have been described previously (Ortega et al. 2009, Stangaferro et al. 2014).

\section{Statistical analysis}

The adequate number of images per follicle and the number of follicles per category were confirmed from a sample size calculation that evaluated the number of samples necessary to produce an estimate of the immunoreactivity that would fall within 0.4 units of the real value. The gene expression levels were analyzed using the REST-2009 program (Pfaffl et al. 2002). SPSS 11.0 for Windows (SPSS) was used to perform the statistical tests. The distribution of data was tested for normality using the Kolmogorov-Smirnov test. Differences between two groups of data were detected by unpaired two-tailed Student's t-test. The differences between more than two groups of data were assessed by one-way ANOVA, followed by Duncan's multiple range tests. $P<0.05$ values were considered significant. Results are expressed as mean \pm standard deviation (s.D.).

\section{Results}

\section{BMP2 expression and localization}

All the follicular samples had weak BMP2 mRNA expression. Moreover, $60 \%$ of the samples expressed this gene outside the linear dynamic range, and so the relative quantification could not be performed.

\section{Control group}
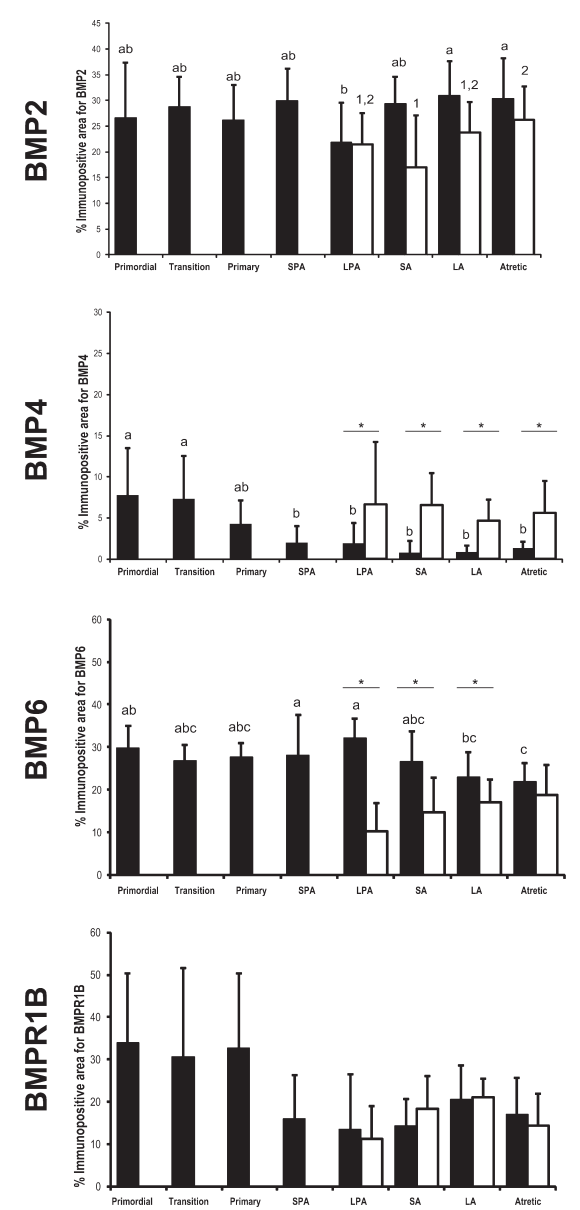

ACTH-Induced COD group
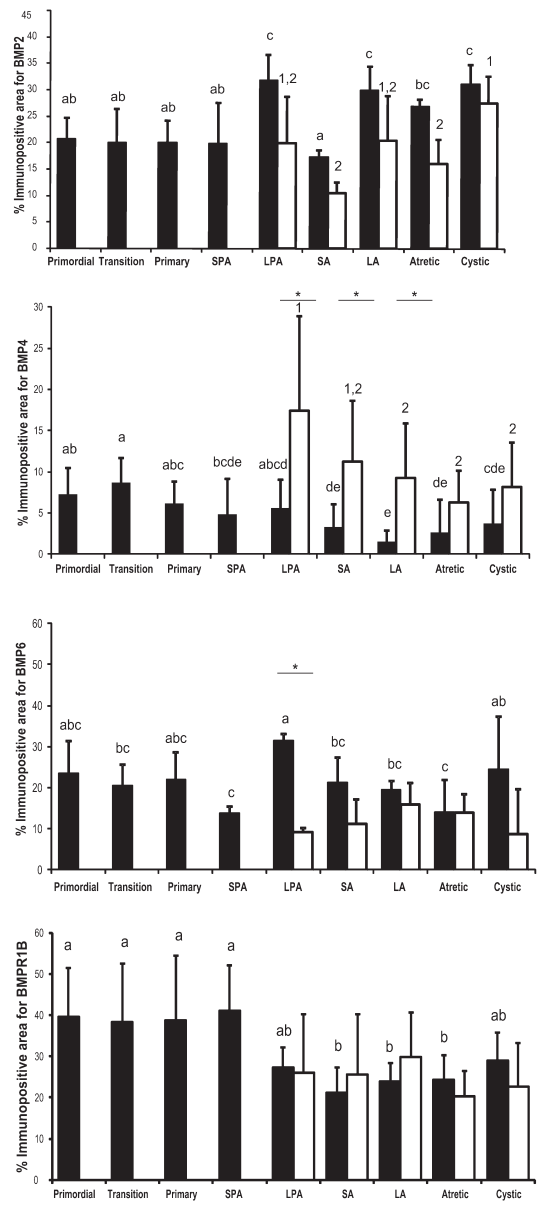

\section{Spontaneous COD group}
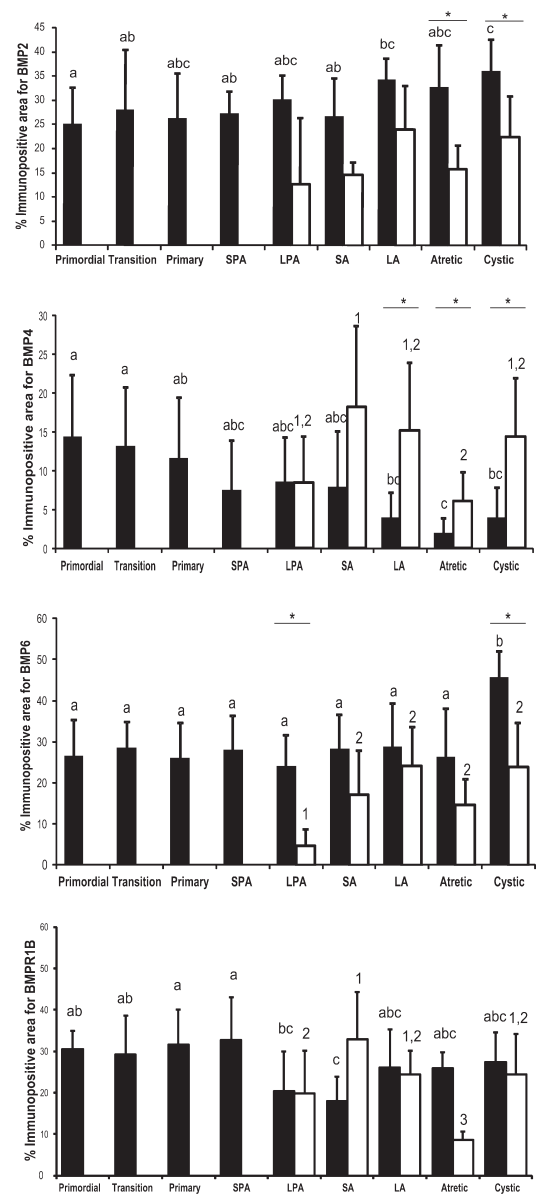

Figure 2 Relative protein expression (measured as percentage of immunopositive area) of BMP2, BMP4, BMP6 and BMPR1B in granulosa (black bars) and theca interna (open bars) cells of different follicular categories (all groups) and cystic follicles (ACTH-induced and spontaneous COD groups) within each group. Values represent mean \pm S.D. Bars with different letters (granulosa) or numbers (theca) are different $(P<0.05)$. Differences between granulosa and theca interna within a follicular category are indicated by an asterisk $(P<0.05)$. 
To obtain information regarding BMP2 localization in different follicular structures, its expression was evaluated by immunohistochemistry and semiquantitative image analysis. BMP2 was localized in the cytoplasm of granulosa and theca interna cells of all follicles and groups analyzed.

\section{Expression of BMP2 during folliculogenesis}

In control animals, BMP2 expression was similar in the granulosa and the theca interna within each follicular category. BMP2 expression in granulosa cells was higher in large antral and atretic follicles than in large preantral follicles $(P<0.05)$, without differences with other categories. In the theca interna, BMP2 expression was lower in small antral follicles than in atretic follicles $(P<0.05)$, without differences with the other follicular categories (Fig. 2).
In the ACTH-induced COD group, BMP2 expression in granulosa cells was higher in large preantral, large antral and cystic follicles than in primordial, transition, primary and small preantral follicles, without differences with atretic follicles $(P<0.05)$. In the theca interna, BMP2 expression was lower in small antral and atretic follicles than in cystic follicles $(P<0.05)$ (Fig. 2).

In animals with spontaneous COD, BMP2 expression in granulosa cells was lower in primordial, transition, small preantral and small antral follicles than in cystic follicles $(P<0.05)$, without differences with large preantral and atretic follicles $(P>0.05)$ (Fig. 2). No differences were observed for theca cell expression for the categories analyzed. The theca cell layer showed lower levels of BMP2 expression than the granulosa cell layer in atretic and cystic follicles $(P<0.05)$ (Fig. 2).

The animals from the progesterone-induced follicular persistence groups showed higher expression in granulosa cells than in theca cells in all follicular
Persistence group: Day 5
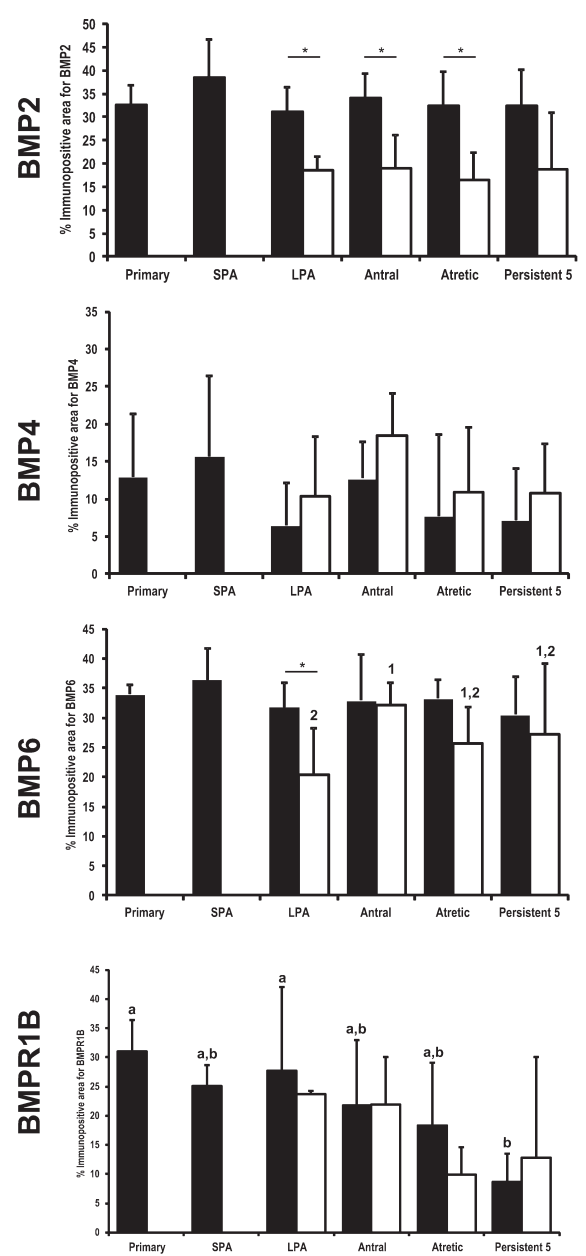

Persistence group: Day 10
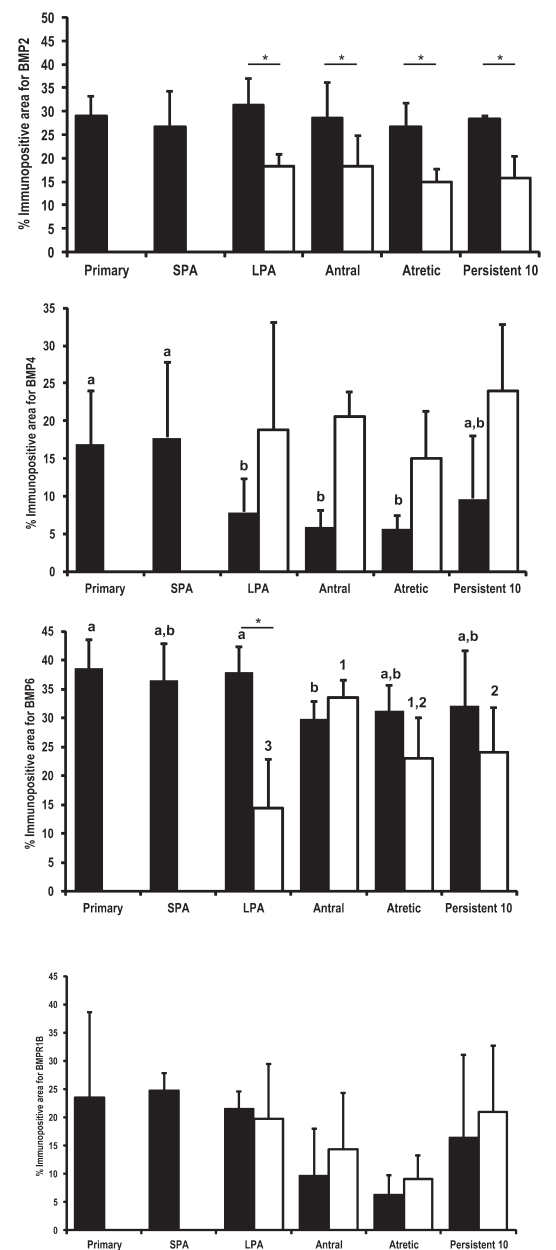

Persistence group: Day 15
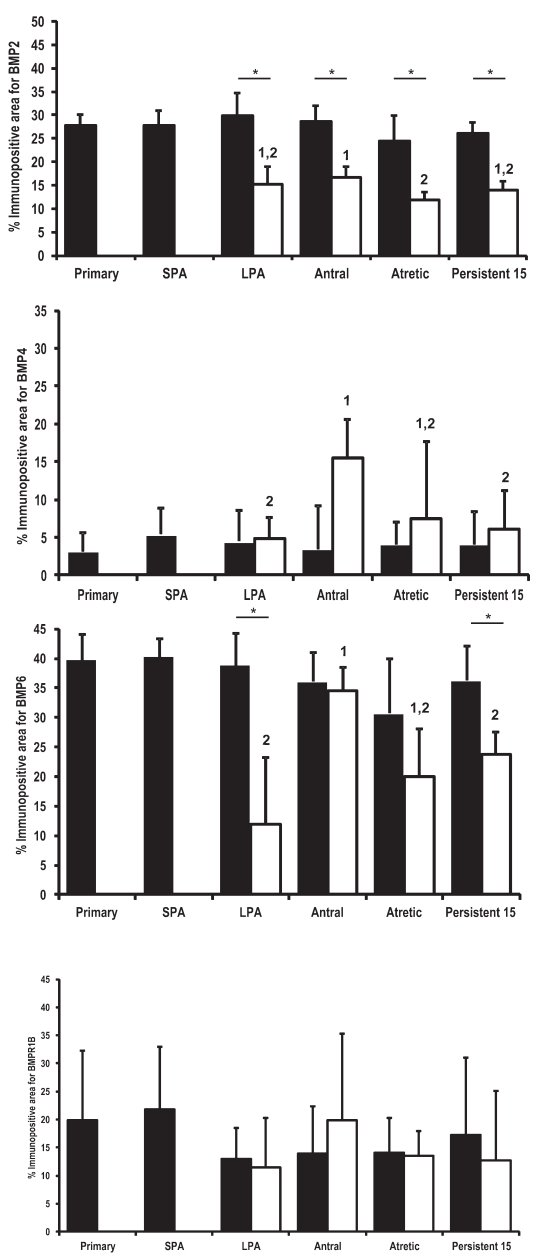

Figure 3 Relative protein expression (measured as percentage of immunopositive area) of BMP2, BMP4, BMP6 and BMPR1B in granulosa (black bars) and theca interna (open bars) cells of different follicular categories and persistent follicles within each group (P5, P10 and P15) of progesterone-induced follicular persistence. Values represent mean \pm S.D. Bars with different letters (granulosa) or numbers (theca) are different $(P<0.05)$. Differences between granulosa and theca interna within a follicular category are indicated by an asterisk $(P<0.05)$. 
categories except in the persistent follicles of group P5 $(P<0.05)$. In the theca interna of group P15, BMP2 expression was lower in atretic than in antral follicles $(P<0.05)$ (Fig. 3).

\section{Comparison of BMP2 expression between groups}

When each specific follicular structure was compared between control, ACTH-induced and spontaneous COD groups, no differences were observed for primordial, transition, primary, large preantral, large antral, atretic and cystic follicles in granulosa cells. In small preantral and small antral follicles, BMP2 expression was higher in the control and spontaneous COD groups than in the ACTH-induced COD group $(P<0.05)$ (Figs 5 and 7). The theca cells of atretic follicles from the control group showed higher BMP2 expression than the ACTHinduced and spontaneous COD groups $(P<0.05)$. No differences were detected in granulosa or theca cells when comparing cysts with large antral follicles (as reference structures) (Figs 5 and 7 ).

Comparison between the control, P5, P10 and P15 groups for each specific follicular category showed higher BMP2 expression in granulosa cells of small preantral follicles from group P5 than in those from the other groups $(P<0.05)$. Theca cells of atretic follicles from groups P10 and P15 showed lower expression than control follicles without differences with group P5 $(P<0.05)$ (Figs 6 and 8).

\section{BMP4 expression and localization}

BMP4 mRNA was detected in all follicular samples analyzed. BMP4 mRNA expression was higher in control samples than in follicular cysts $(P<0.05)$ (Fig. 4). BMP4 was localized, by immunohistochemistry, in the cytoplasm of granulosa and theca interna cells of all follicles and groups analyzed.

\section{Expression of BMP4 during folliculogenesis}

The control group showed greater expression in theca cells than in granulosa cells for the same follicular category. The expression in granulosa cells was higher in primordial and transition follicles than in small and large preantral, small and large antral and atretic follicles $(P<0.05)$, without differences with primary follicles $(P>0.05)$. In theca cells, no differences were detected between the different follicular structures evaluated (Fig. 2).

In animals with ACTH-induced COD, BMP4 expression was greater in theca cells than in granulosa cells for the same category in large preantral and small and large antral follicles $(P<0.05)$. In the granulosa cell layer, primordial and transition follicles showed higher expression than small and large antral, atretic and cystic follicles $(P<0.05)$. BMP4 expression was higher in theca cells of large preantral follicles than large antral, atretic and cystic follicles $(P<0.05)$ (Fig. 2$)$.
In animals with spontaneous COD, the pattern was similar to that observed in those with ACTH-induced COD, with higher expression in theca cells of large antral, atretic and cystic follicles than in granulosa cells of the same categories $(P<0.05)$. In granulosa cells, BMP4 expression was lower in large antral, atretic and cystic follicles than in primordial and transition follicles $(P<0.05)$, whereas in theca cells, BMP4 expression was higher in small antral than in atretic follicles $(P<0.05)$ (Fig. 2).

In group P10, BMP4 expression was higher in granulosa cells of primary and small preantral follicles than in those of large preantral, antral and atretic follicles. In the theca interna of group P15, the lowest expression was seen in large preantral and persistent follicles $(P<0.05)$ (Fig. 3).

\section{Comparison of BMP4 expression between groups}

Comparison of each specific follicular structure between the control, ACTH-induced COD and spontaneous COD groups showed that the granulosa cells of animals with spontaneous COD showed higher expression in primordial, primary and large antral follicles than those of the control and ACTH-induced COD groups and higher expression in large and small antral follicles than those of the control group, without differences with the ACTH-induced COD group $(P<0.05)$ (Fig. 5). In theca cells, large antral follicles from the spontaneous COD group showed higher expression than the control group, and spontaneous cysts showed higher expression than ACTH-induced cysts $(P<0.05)$ (Fig. 5). Comparison of BMP4 expression in theca cells between small and large antral follicles from the control group (as reference

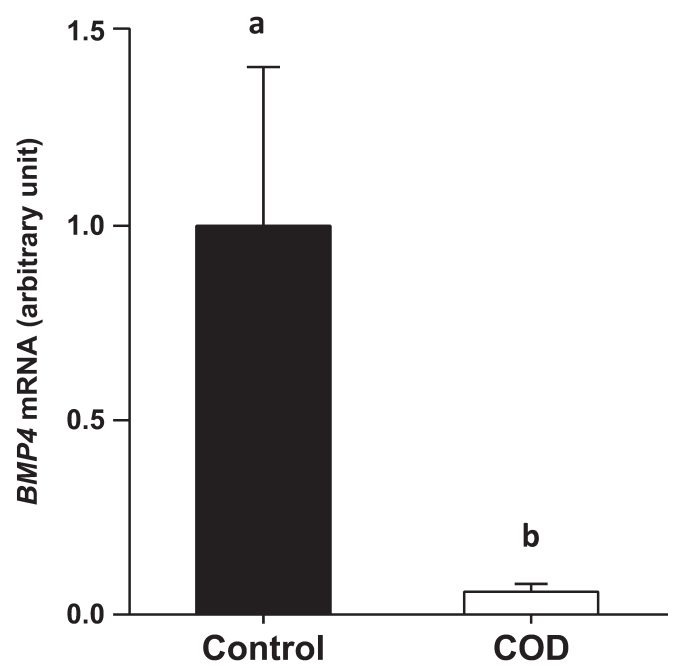

Figure 4 BMP4 mRNA expression levels in follicular cells from spontaneous cystic ovaries (COD, $n=10$, mean diameter: $25.8 \pm 3.6 \mathrm{~mm}$ ) (open bars) related to control ovaries $(n=10$, mean diameter: $11.8 \pm 1.7 \mathrm{~mm}$ ) (black bars) by real-time PCR. Values represent the mean \pm S.D. Bars with different letters are significantly different $(P<0.05)$. 
Granulosa cells
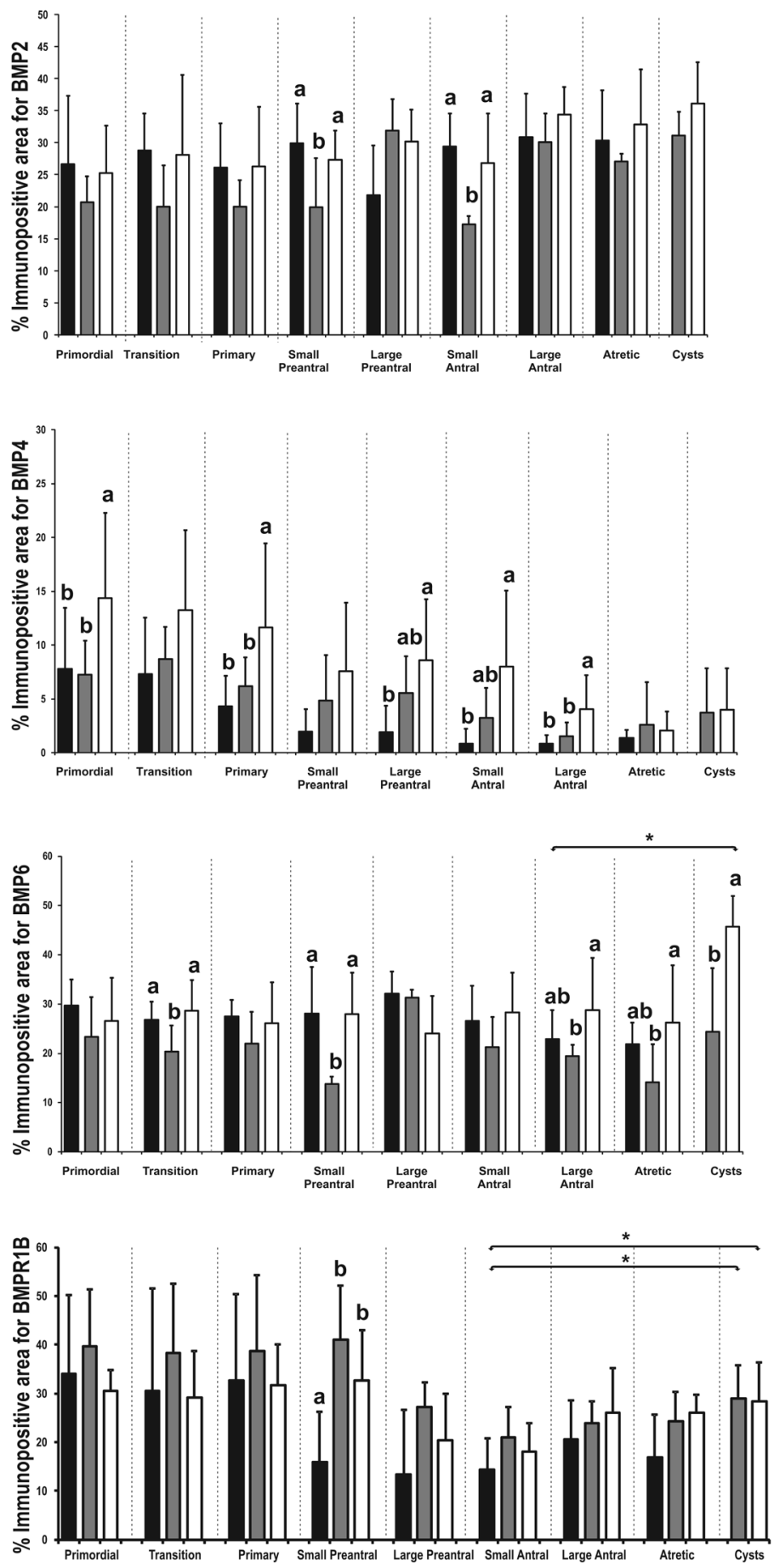

Theca cells
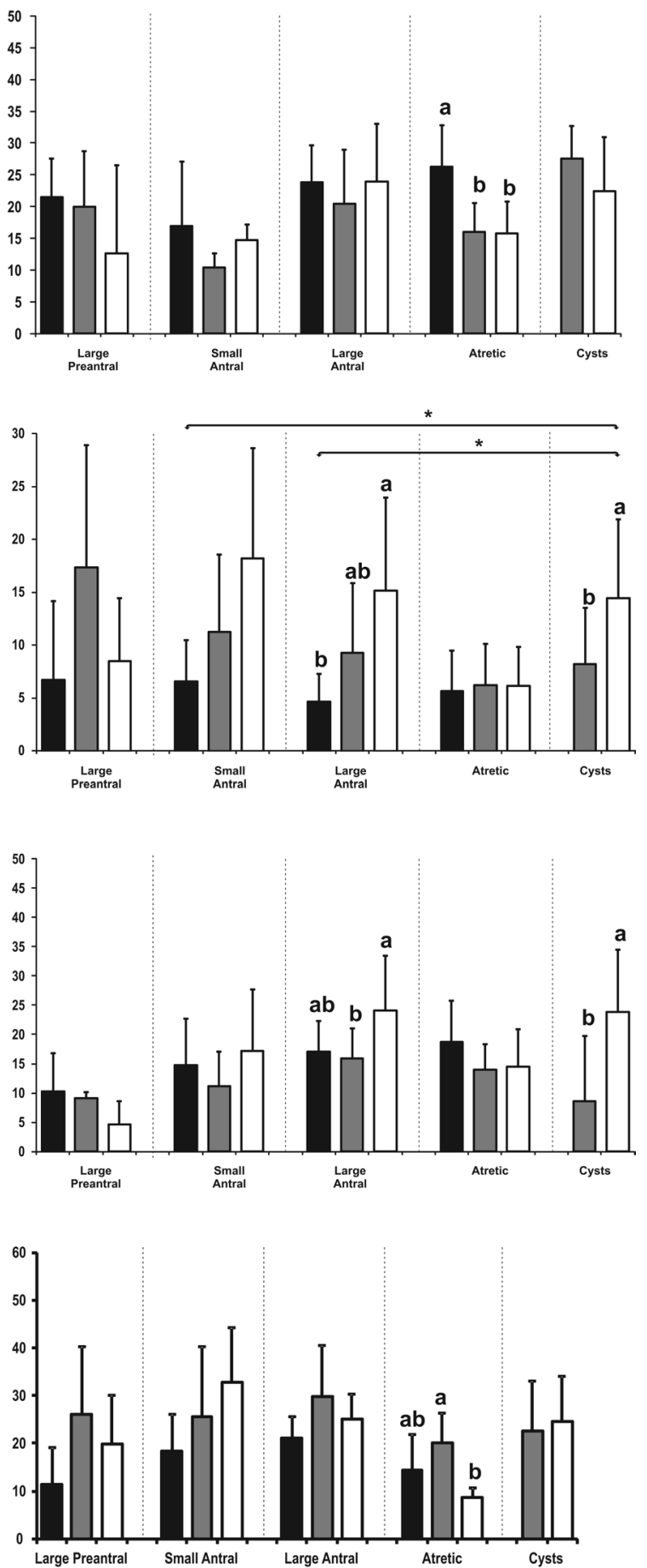

Figure 5 Relative protein expression (measured as percentage of immunopositive area) of BMP2, BMP4, BMP6 and BMPR1B in different follicular categories from the control, ACTH-induced COD and spontaneous COD groups in granulosa and theca interna cells of primordial, transition, primary, small and large preantral, small and large antral and atretic follicles from the control group (black bars); ACTH-induced COD group (gray bars); spontaneous COD group (open bars); and spontaneous and ACTH-induced cysts. Values represent mean \pm s.D. Bars with different letters within a category are significantly different $(P<0.05)$. Asterisks indicate differences between spontaneous cysts and small and large antral follicles from the control group $(P<0.05)$.

structures) and cysts (ACTH-induced and spontaneous follicular cyst groups) showed higher expression in spontaneous cysts $(P<0.05)$ (Figs 5 and 7$)$.
Comparison between the control, P5, P10 and P15 groups for each specific follicular category showed higher BMP4 expression in granulosa cells of primary and 
small preantral follicles from groups P5 and P10 than in those from the control and P15 groups $(P<0.05)$. Antral follicles showed higher expression in group P5 than in the control and P15 groups $(P<0.05)$. Comparison between antral follicles from the control group (as reference structure) with persistent follicles showed higher expression in persistent follicles from group P10
$(P<0.05)$. Theca cells of antral follicles from persistent groups showed higher expression than control follicles, whereas atretic follicles showed higher expression in group P10 than in the control and P15 groups, without differences with group P5 $(P<0.05)$. Persistent follicles from group P10 showed higher expression than those of groups P5 and P15 $(P<0.05)$ (Figs 6 and 8$)$.

\section{Granulosa cells}
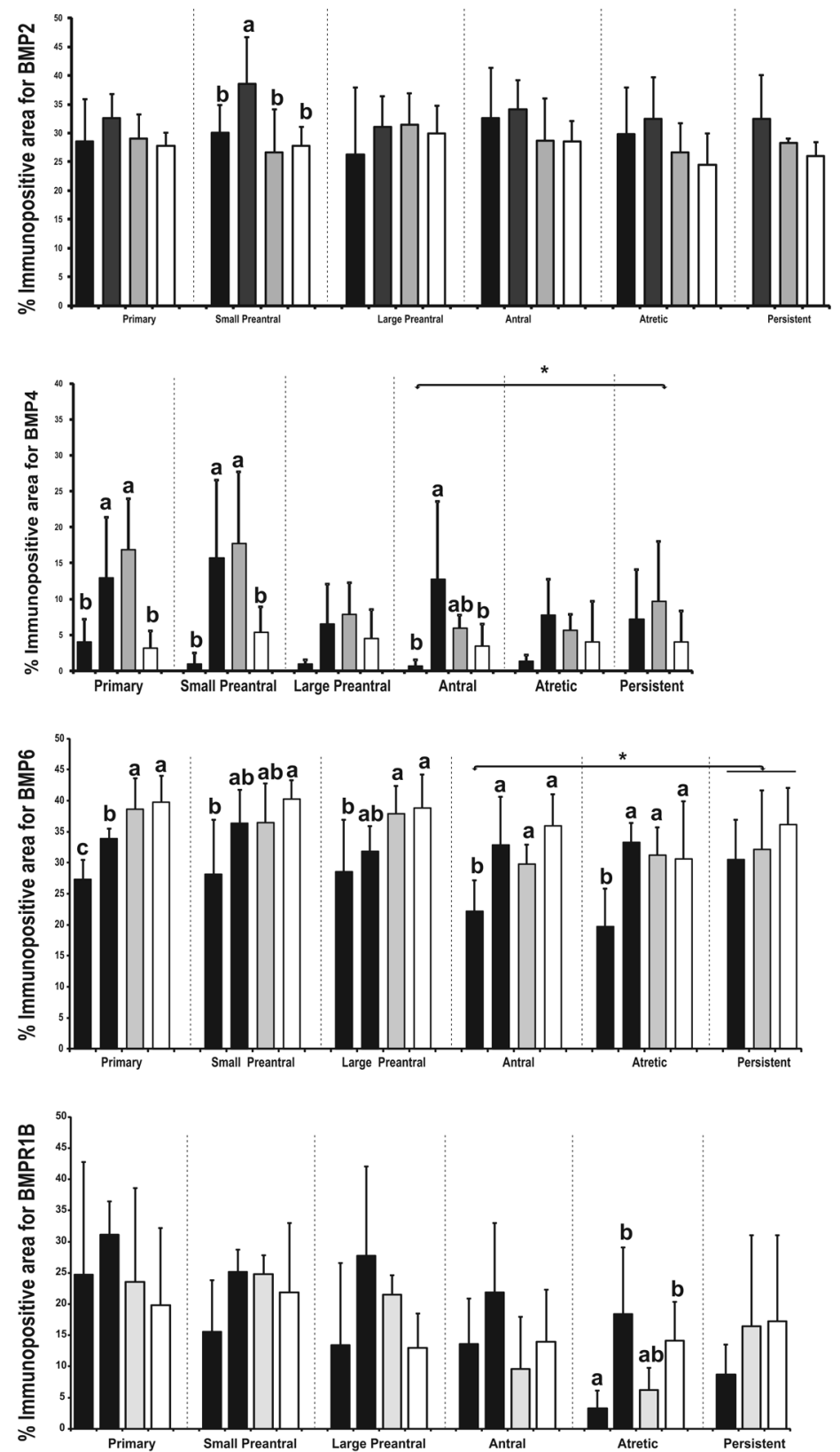

Theca cells
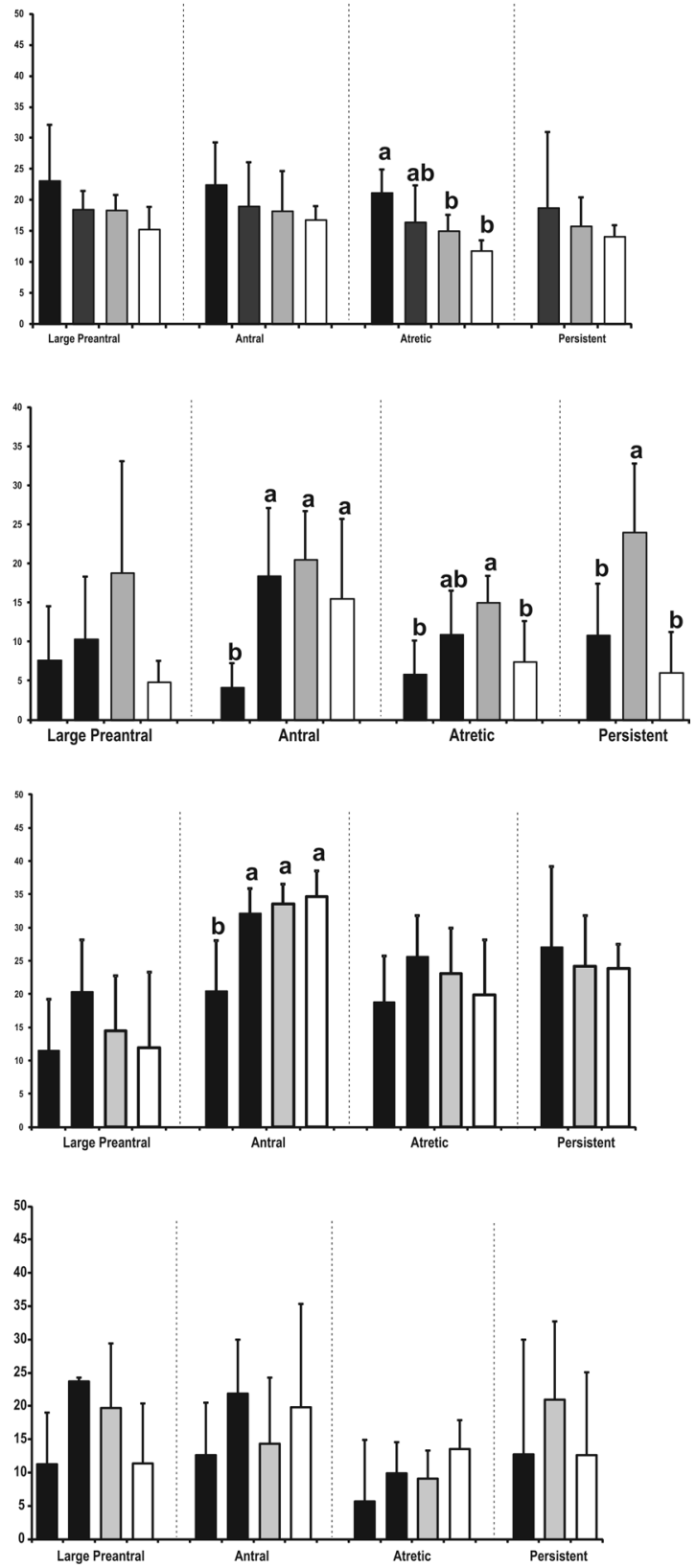

Figure 6 Relative protein expression (measured as percentage of immunopositive area) of BMP2, BMP4, BMP6 and BMPR1B in different follicular categories from the control and P5, P10 and P15 progesterone-induced follicular persistence groups in granulosa and theca interna cells of primary, small and large preantral, antral and atretic follicles from the control (black bars), P5 (dark gray bars), P10 (light gray bars) and P15 (open bars) groups and persistent follicles from the P5, P10 and P15 groups. Values represent mean \pm S.D. Bars with different letters within a category are significantly different $(P<0.05)$. Asterisk indicates differences between persistent follicles and antral follicles from the control group $(P<0.05)$ 


\section{BMP6 expression and localization}

All the follicular samples had weak BMP6 mRNA expression. Moreover, $80 \%$ of the samples expressed this gene outside the linear dynamic range, and so the relative quantification could not be performed. BMP6 was localized by immunohistochemistry in the cytoplasm of granulosa and theca interna cells of all follicles and groups analyzed.

\section{Expression of BMP6 during folliculogenesis}

Granulosa cells from the control animals showed high expression in small and large preantral follicles in comparison with large antral and atretic follicles. No differences were observed in theca cells in the follicular categories evaluated. Also, expression was higher in granulosa cells than in theca cells of the same category for large preantral and small and large antral follicles $(P<0.05)$ (Fig. 2).

In the ACTH-induced COD group, granulosa cells showed higher expression in large preantral follicles than in transition, small preantral, small and large antral and atretic follicles. However, cystic follicles showed higher expression than small preantral and atretic follicles $(P<0.05)$. Theca cells showed lower BMP6 expression than granulosa cells in large preantral follicles $(P<0.05)$ (Fig. 2).

In animals with spontaneous COD, granulosa cells of cystic follicles showed higher BMP6 expression than all the other follicular categories $(P<0.05)$. Theca cells of large preantral follicles showed lower BMP6 expression than the other follicular categories. Within the same follicular category, granulosa cells showed higher BMP6 expression than the respective theca cells of large preantral and cystic follicles $(P<0.05)$ (Fig. 2).
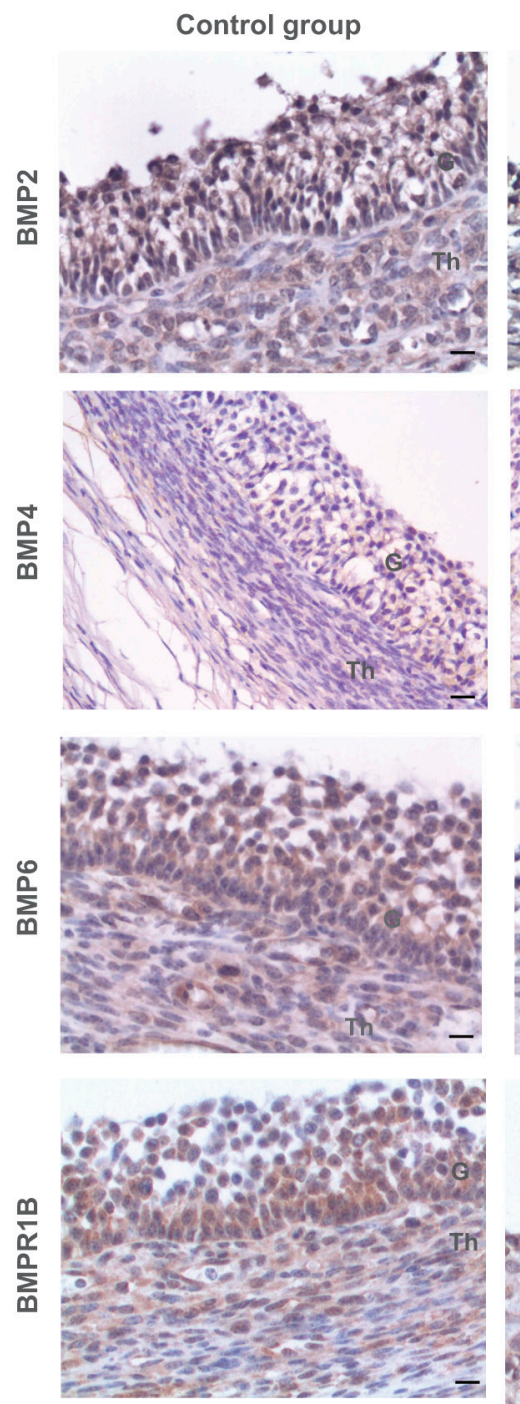
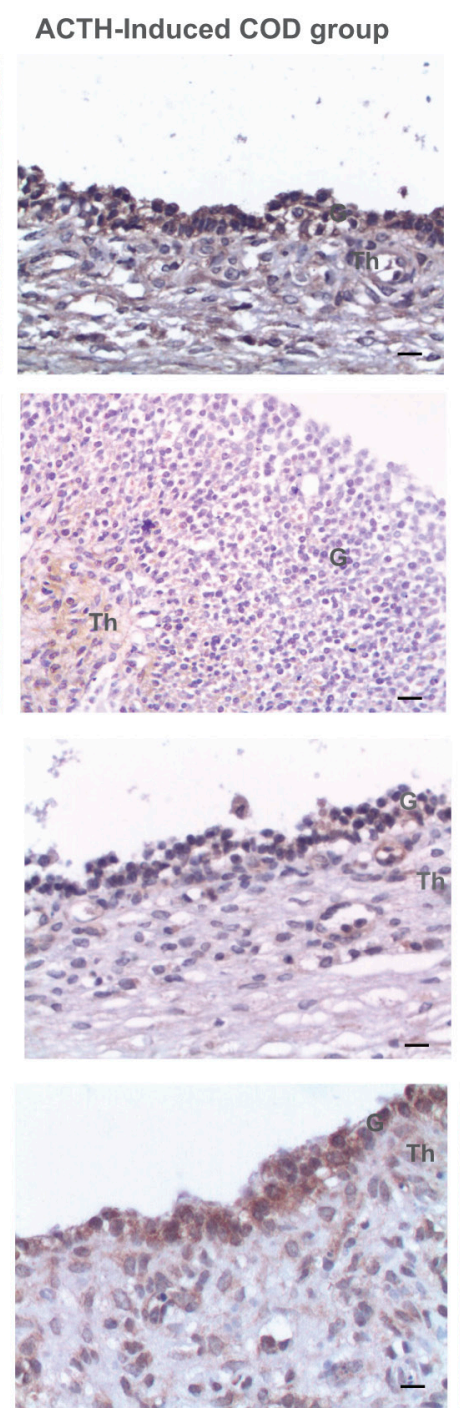

Spontaneous COD group
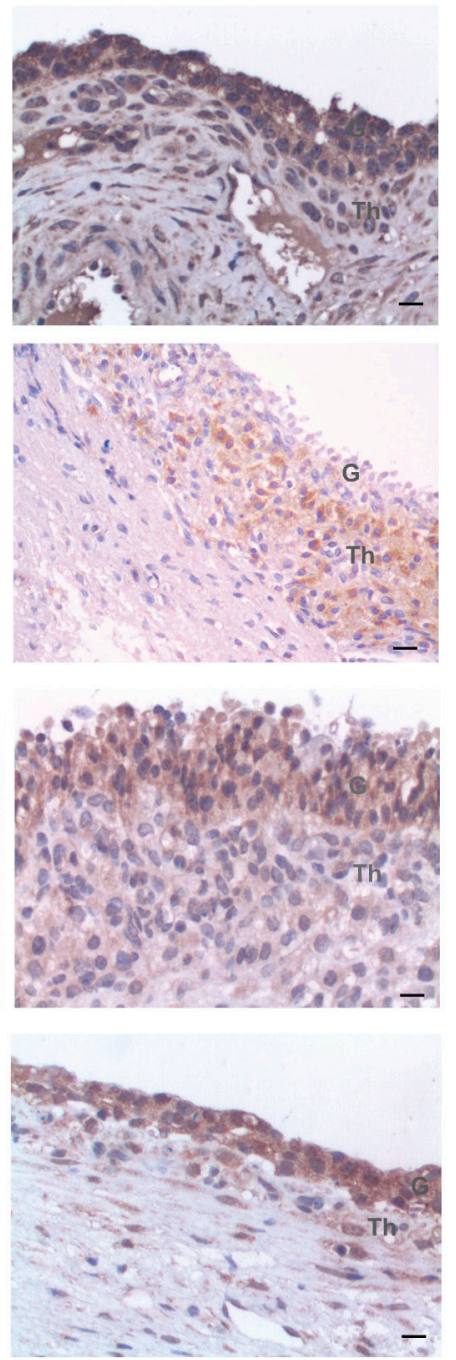

Negative control
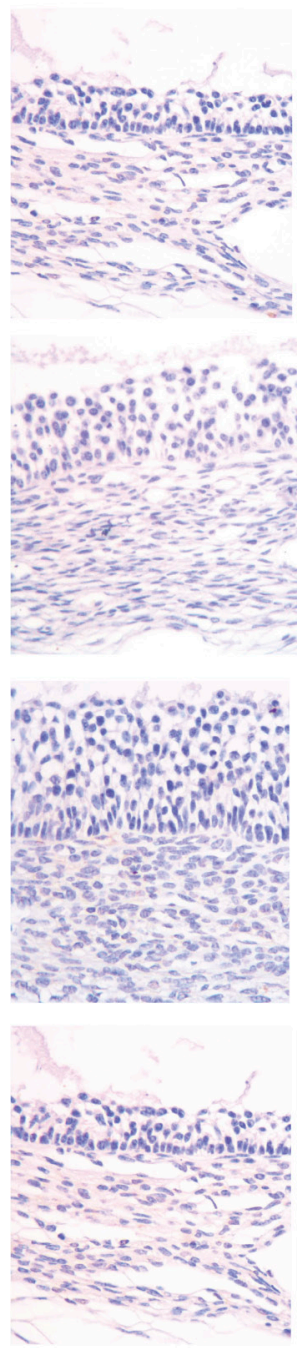

Figure 7 Representative images of BMP2, BMP4, BMP6 and BMPR1B immunostaining in antral follicles (control group) and cystic follicles of ACTH-induced and spontaneous COD groups. Granulosa (G), theca interna (Th). Bars $=20 \mu \mathrm{m}$. A negative control of immunohistochemistry is shown in the right panel. 
The animals from the progesterone-induced follicular persistence groups showed higher BMP6 expression in granulosa cells of primary and large preantral than in those of antral follicles in group P10. In the theca interna of all groups, BMP6 expression was higher in antral follicles than in large preantral follicles. In groups P10 and P15, theca cells of persistent follicles showed lower expression than antral follicles $(P<0.05)$ (Fig. 3).

\section{Comparison of BMP6 expression between groups}

Comparison between groups for equivalent follicular structures showed differences in the granulosa of transition and small preantral follicles with lower expression in the $\mathrm{ACTH}$-induced COD group than in the control and spontaneous COD groups $(P<0.05)$. Large antral and atretic follicles showed higher expression in follicles of animals with spontaneous COD than in those with ACTH-induced COD $(P<0.05)$, without differences with controls. Spontaneous follicular cysts showed higher expression than ACTH-induced cysts. Comparison of cysts with small or large antral follicles (as reference structures) showed that spontaneous cysts showed higher BMP6 expression than large antral follicles from the control group $(P<0.05)$. In theca cells, BMP6 expression was higher in large antral and cysts from the spontaneous COD group than in those from the ACTH-induced COD $(P<0.05)$, without differences with the control group $(P>0.05)$ (Figs 5 and 7$)$.
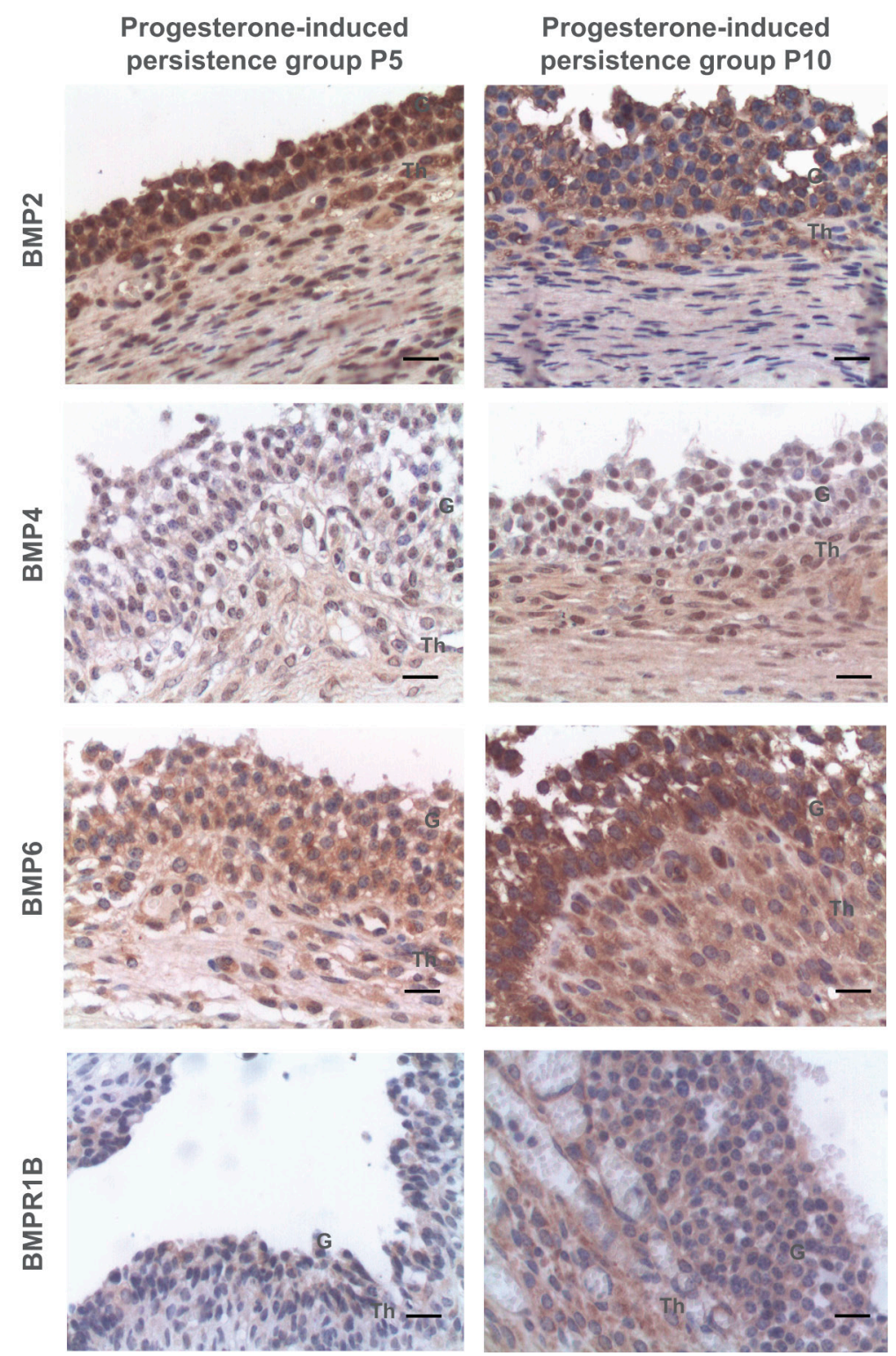
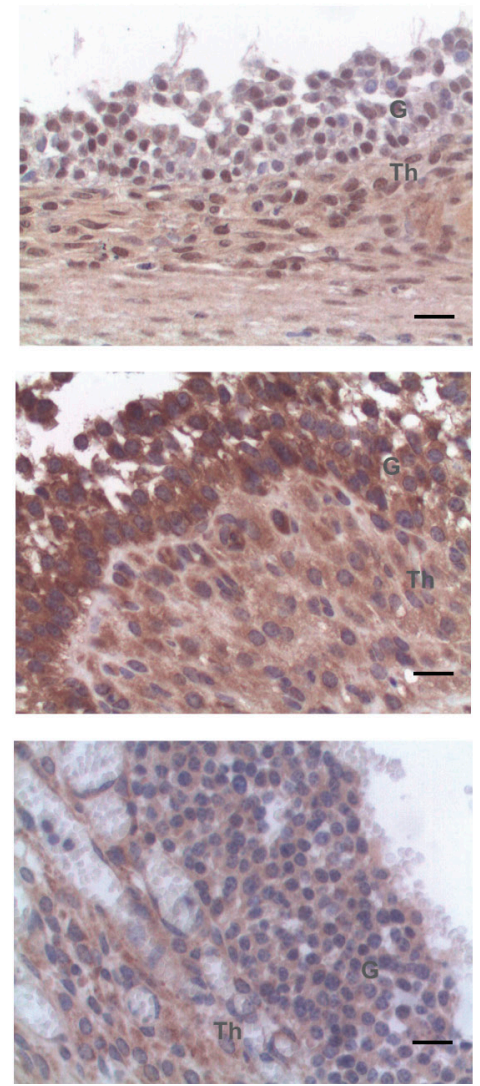

\section{Progesterone-induced persistence group P15}
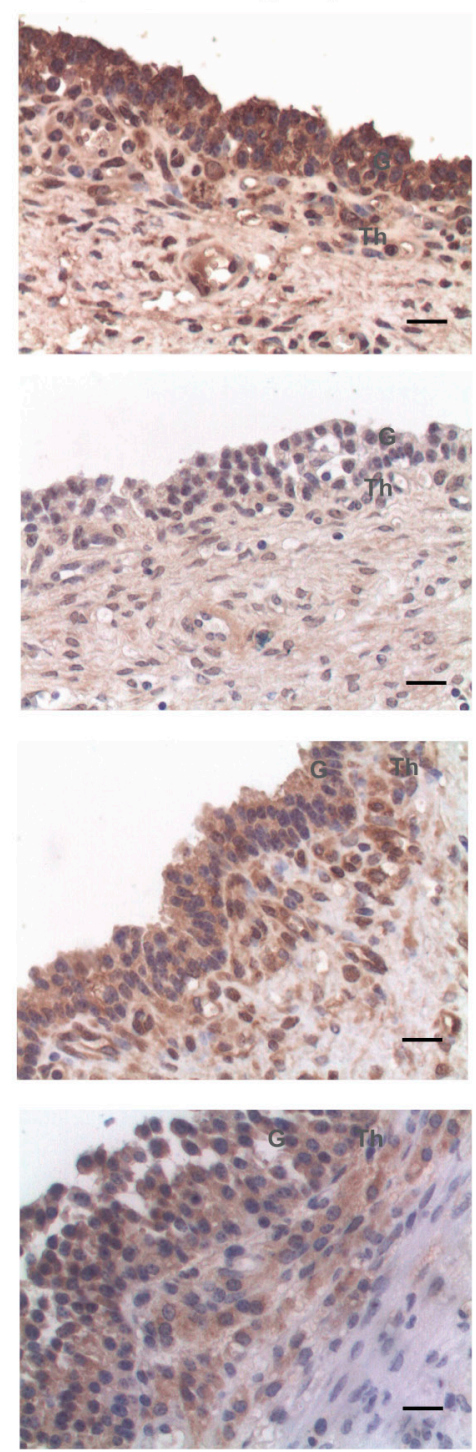
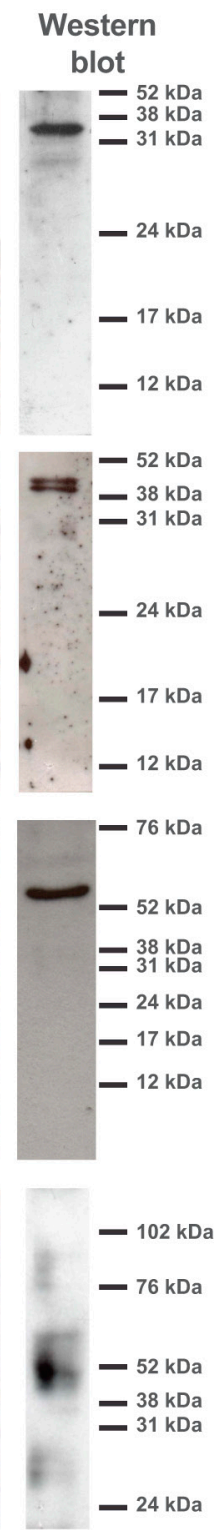

Figure 8 Representative images of BMP2, BMP4, BMP6 and BMPR1B immunostaining in persistent follicles of the P5, P10 and P15 groups. Granulosa $(\mathrm{G})$, theca interna (Th). Bars $=20 \mu \mathrm{m}$. A representative Western blot is shown in the right panel. 
Comparison between the control, P5, P10 and P15 groups for each specific follicular category showed higher BMP6 expression in granulosa cells of primary, antral and atretic of all persistence groups than in those of the control group $(P<0.05)$. Also, small and large preantral follicles from group P15 showed higher expression than the control $(P<0.05)$. Comparison of BMP6 expression in granulosa cells of antral follicles from the control group (as reference structure) with persistent follicles showed higher expression in persistent follicles of all groups $(P<0.05)$. Theca cells of antral follicles from groups P5, P10 and P15 showed higher expression than those of the control group $(P<0.05)$ (Figs 6 and 8 ).

\section{BMPR1B expression and localization}

BMPR1B was localized in the cytoplasm of both granulosa and theca interna cell layers of all follicles and groups analyzed.

\section{Expression of BMPR1B during folliculogenesis}

Granulosa cells of the control group showed no differences between the different categories, but a statistical tendency between primordial and primary follicles related to large preantral and small antral follicles was observed $(P=0.1)$. No differences were detected in the theca cells of the categories analyzed (Fig. 2). In the ACTH-induced COD group, BMPR1B expression in granulosa cells was higher in primordial, transition, primary and small preantral follicles than in small and large antral and atretic follicles $(P<0.05)$. No differences were detected in theca cells (Fig. 2).

In animals with spontaneous COD, granulosa cells of primary and small preantral follicles showed higher BMPR1B expression than large preantral and small antral follicles $(P<0.05)$. In theca cell layers, the lowest expression was observed in atretic follicles related to the other follicular categories $(P<0.05)$ (Fig. 2$)$.

In group P5, BMPR1B expression was lower in granulosa of persistent follicles than in those of primary and large preantral follicles $(P<0.05)$ (Fig. 3).

\section{Comparison of BMPR1B expression between groups}

Comparison between groups for equivalent follicular structures showed differences in the granulosa of small preantral follicles, with higher expression in the ACTHinduced and spontaneous COD groups than in the control group $(P<0.05)$. Comparison of cysts with reference structures (small and large antral follicles) from the control group showed that ACTH-induced and spontaneous cysts presented higher BMPR1B expression than small antral follicles from the control group $(P<0.05)$. In theca cells, BMPR1B expression was higher in atretic follicles from the $\mathrm{ACTH}$-induced group than in those from the spontaneous COD group $(P<0.05)$, without differences with the control group $(P>0.05)$ (Figs 5 and 7$)$.
Comparison between control and progesteroneinduced persistence groups for each follicular category showed higher BMPR1B expression in granulosa cells of atretic follicles of groups P5 and P15 than in those of the control group $(P<0.05)$ (Figs 6 and 8$)$.

\section{Discussion}

In this study, we evaluated three of the most important BMPs and BMPR1B in animals with spontaneous COD as well as in two experimental models. We performed this evaluation during folliculogenesis to determine changes over its course and then compared results between groups to detect changes related to the control group. Changes in BMP2, BMP4 and BMP6 expression in granulosa and theca cells of the COD group, during folliculogenesis as well as at the different stages of follicular persistence were detected. Variations in BMPR1B expression in developing follicles of animals with COD, and at the initial stages of follicular persistence (P5), were also detected. Comparison between groups showed significant differences, mainly in BMP4 and BMP6 expression, in granulosa and theca cells of different follicular categories. The expression of these BMPs was also increased in cystic and persistent follicles, in relation to antral follicles (as reference structure) of the control group. BMPR1B showed higher expression in cystic follicles.

During folliculogenesis, in different groups, BMP2 expression increased slightly in more advanced stages of follicular development and cysts (spontaneous and ACTH-induced). The data presented here are consistent with previous descriptions of the pattern of expression of BMP2 in somatic cells of the ovary (Glister et al. 2010). Additionally, these authors found a negative correlation between BMP2 and other key transcripts, including CYP19, inhibin A, inhibin BA and inhibin BB, upregulated in granulosa cells of estrogen-active follicles. In contrast, Selvaraju et al. (2013) observed a stagespecific regulation of BMP2, with highest expression in preovulatory follicles of cattle. These authors postulated that a temporal regulation of BMP2 mRNA supports a potential local regulatory role in the development of the dominant follicle.

BMP4 protein expression decreased during folliculogenesis, a pattern that was repeated in the ACTH-induced and spontaneous COD groups and in the P10 group of progesterone-induced persistence. Expression in theca cells was much higher than that in granulosa cells, but the expression pattern in the different cellular populations was similar, with a decrease in relation to follicular development. The localization and pattern distribution of BMP4 have been extensively described by various authors. In this sense, Fatehi et al. (2005) found no BMP4 protein expression in granulosa cells of growing follicles, despite having shown mRNA expression in granulosa and theca of antral follicles 
less than $8 \mathrm{~mm}$ in diameter. However, Glister et al. (2010) and Kayani et al. (2009) showed BMP4 mRNA expression and immunoreactive protein in both theca and granulosa cells, although BMP4 transcripts were more abundant in theca than in granulosa cells, in agreement with earlier immunocytochemical evidence in cattle (Glister et al. 2004) and other species (Khalaf et al. 2013).

BMP6 mRNA was detected in control samples of antral estrogen-active follicles and protein expression was detected in granulosa and theca cells of all the follicular structures analyzed. BMP6 protein expression was lower in granulosa cells of atretic follicles than in primordial and small and large preantral follicles in control ovaries, without significant differences during folliculogenesis in granulosa or theca interna cells in this group. In the ovaries of animals with spontaneous COD, BMP6 expression was higher in cysts than in the other follicular structures. Moreover, BMP6 expression was lower in theca cells from persistent follicles from groups P10 and P15 than in their respective antral follicles. Glister et al. (2010) found that the relative abundance of BMP6 mRNA in granulosa or theca cells has little or no variation across antral follicle development. However, it must be noted that the evaluation by Glister et al. (2010) was conducted only in developing antral follicles but not during folliculogenesis as in this study.

In control bovine ovaries, BMPR1B protein expression was constant at all stages of follicular development in both granulosa and theca interna cells. In the ACTHinduced COD group, BMPR1B expression decreased in granulosa cells during folliculogenesis, a pattern that was partially repeated in the spontaneous COD group, where large antral follicles showed levels of expression similar to those of preantral follicles. Also, BMPR1B expression showed a decrease in group P5 during folliculogenesis, mainly in the persistent follicles. In cattle, Glister et al. (2010) described that the expression of both BMPR1B and BMPR2 increases progressively in granulosa cells and decreases slightly in theca cells along antral follicular development. Particularly, they found that BMPR1B is increased in antral follicles of $9-10 \mathrm{~mm}$ in comparison with antral follicles of $1-2 \mathrm{~mm}$ in diameter (Glister et al. 2010). This suggests a progressive shift in the balance of granulosa/theca responsiveness to an intrafollicular BMP ligand that signals via this particular combination of type 1 and type 2 receptors. In this way, granulosa cells become more responsive, whereas theca cells become less responsive as antral follicles increase in size (Glister et al. 2010). Ligands known to recruit the combination of type 1 and type 2 signaling receptors include BMP2, BMP4, BMP6, BMP7 and BMP15 (Glister et al. 2010).

The comparison between experimental groups and the corresponding control groups showed alterations in the expression for the BMPs studied and BMPR1B. BMP2 expression was not much altered at early stages of follicular development, and these changes were only observed in animals with ACTH-induced COD and in group P5 of the progesterone-induced persistence model relative to the control group. However, these changes were not reflected in the other follicular categories. However, BMP4 and BMP6 expressions were remarkably altered in the groups evaluated. BMP4 expression was significantly increased in the follicles from spontaneous COD animals and animals with follicular persistence in the preantral (as from the primordial follicles category) and antral categories. BMP4 expression was also increased in cystic (in the theca interna) and persistent follicles (in granulosa) in relation to reference structures. As detailed previously, the changes were detected early in animals with follicular persistence (P5) as well as throughout persistence (P15). However, this did not match the decrease in mRNA observed in the spontaneous COD group. This was probably due to the cellular composition of the samples in which mRNA expression was analyzed (composed of theca and granulosa cells) and the type of antral follicles used as controls for the mRNA study (only 'estrogen-active' follicles were analyzed). Moreover, due to the persistence time of the spontaneous cystic follicles, it is likely that part of the mRNA was degraded by the enzymes present in the FF (Borbolis \& Syntichaki 2015). Regarding BMP6, changes occurred in the same direction as those observed for BMP4, but mainly in the granulosa cell layer. Persistent follicles behaved like cystic follicles (from spontaneous COD animals), which could indicate that changes occur early and are maintained over time, affecting the normal ovarian function. BMPR1B exhibited small changes between groups for the follicular categories analyzed, except for the comparison between ACTH-induced and spontaneous cysts with antral follicles from the control group, as reference structures, where the expression was increased in the granulosa of cysts. Nevertheless, this did not match that observed in the groups with progesterone-induced follicular persistence.

Differences in the expression of the BMP components analyzed were detected as from very early stages of follicular growth and incipiently during the development of the disease. The expression of BMP2, BMP4, BMP6 and BMPR1B in developing follicles was altered as from preantral stages. Considering the high level of recurrence of COD, the changes in early follicular development can affect the future folliculogenesis and could thus contribute to the high rate of recurrence reported for this disease by many authors (Silvia et al. 2002, Vanholder et al. 2006). It has been widely reported that normal cyclicity can resume following the regression of a cyst; however, it is more common for regressing cysts to be replaced by new cysts. The phenomenon of cyst replacement, which is usually termed turnover, has been observed in various studies (Carroll et al. 1990, Yoshioka et al. 1996, Silvia et al. 2002). Like the changes in the expression of these 
factors, which occur at early stages of folliculogenesis in diseased animals, these same alterations were present as early as 5 days of persistence in the model of progesterone-induced follicular persistence. This could indicate that the follicles quickly change and that these changes are permanent throughout COD development. Thus, the processes involved in proper development and follicular maturation could be affected, preventing ovulation and contributing to follicular persistence.

Considering the roles of BMPs in the ovary such as suppression of CYP17 expression (Glister et al. 2010, 2011); reduction of LHCGR, StAR, CYP11A1 and HSD3B expressions (Glister et al. 2011); stimulation of granulosa cell $17 \beta$-estradiol production; and inhibition of progesterone and androgen production and considering that BMP4 and BMP6 expressions are increased in spontaneous cysts and persistent follicles, it is plausible to postulate that the increased expression of these BMPs contributes to the hormonal imbalance at local level observed previously in COD animals (Amweg et al. 2013) as well as in the progesteroneinduced follicular persistence model (Díaz et al. 2015). Animals with spontaneous and ACTH-induced COD have low serum and intrafollicular levels (in cysts) of progesterone, without differences in $17 \beta$-estradiol concentrations when compared with preovulatory follicles (Amweg et al. 2013). This overlaps with the hormone levels found in animals with progesteroneinduced follicular persistence, where progesterone levels in FF remained lower than and $17 \beta$-estradiol levels remained similar to those of control animals, except in group P15, where they decreased (probably due to a decrease in the population of granulosa cells responsible for the aromatization of androgens). Moreover, testosterone levels in FF were increased in animals with spontaneous COD, coinciding with levels in persistent follicles, where testosterone levels increased gradually to the extent that persistence progressed, resembling spontaneous cysts, with follicles of 15 days of persistence. The high levels of BMP4 and BMP6 in ovaries from animals with spontaneous COD and progesterone-induced follicular persistence can contribute to this imbalance, which eventually results from the sum of many local and general factors (Amweg et al. 2013, Díaz et al. 2015). We have noted previously that other members of the TGF- $\beta$ and IGF systems are altered in the ovaries of animals with COD (Ortega et al. 2008, Rey et al. 2010, Rodríguez et al. 2011, 2013, 2015, Stangaferro et al. 2014, Matiller et al. 2014, Ortega et al. 2015). Such hormonal imbalance could affect, among others, the balance between proliferation and apoptosis and between pro- and anti-apoptotic factors in ovarian follicles of animals with COD. We and others have confirmed previously that the proliferation/apoptosis balance is altered in cystic follicles in animals with spontaneous and ACTH-induced COD, favoring the persistence of follicles because of low proliferation of follicular cells and a low rate of apoptosis (Isobe \& Yoshimura 2007, Salvetti et al. 2010).

Based on our results, we could postulate that the delicate balance between the components of the BMP system is altered. This might contribute to the mechanisms that lead to prolonged follicular persistence, with low levels of apoptosis and proliferation in these structures (Isobe \& Yoshimura 2007, Salvetti et al. 2010) and with an altered steroidogenesis in response to gonadotropin stimuli (Amweg et al. 2013, Díaz et al. 2015), collaborating with COD recurrence.

Finally, the differences found between animals with spontaneous and $\mathrm{ACTH}$-induced COD are probably due to the differences in the environmental conditions and the time of persistence of the cysts, which could influence the expression of these components. However, the similarities found between the model of follicular persistence induced by progesterone at 15 days of persistence and spontaneous follicular cysts support the conclusion that this is a good model to study the disease as from the early events of its development.

In summary, the present results, together with previous results, indicate that there is an imbalance in the expression of the components of the TGF- $\beta$ superfamily, more specifically in the BMP system, which could contribute to follicular persistence and hormonal changes at local level and thus contribute to the pathogenesis of bovine COD.

\section{Declaration of interest}

The authors declare that there is no conflict of interest that could be perceived as prejudicing the impartiality of the research reported.

\section{Funding}

This study was supported by a grant from the Argentine National Agency for the Promotion of Science and Technology (ANPCyT) (PICT 2008-1952/ 2011-1274). G J H, F R, H H O and N R S are Research Career Members, and P U D, V M and $M E B$ are fellows of the National Scientific Research Council (CONICET, Argentina).

\section{Acknowledgements}

The authors are grateful to the staff of the Large Animal Health Hospital of the Facultad de Ciencias Veterinarias de la Universidad Nacional del Litoral for the animal care and help with the generation of the experimental animals and collection of samples. They also thank DVM Jose Bertoli and DVM Fabian Barberis for the assistance with the animal care, the staff members of the Laboratorio de Biología Celular y Molecular Aplicada (ICIVET-Litoral UNL CONICET) for their technical support during processing of the slides and Novartis Laboratories for the provision of drugs. 


\section{References}

Amweg AN, Salvetti NR, Stangaferro ML, Paredes AH, Lara $\mathrm{HH}$, Rodríguez FM \& Ortega HH 2013 Ovarian localization of $11 \beta$-hydroxysteroid dehydrogenase $(11 \beta \mathrm{HSD})$ : effects of ACTH stimulation and its relationship with bovine cystic ovarian disease. Domestic Animal Endocrinology 45 126-140. (doi:10.1016/j. domaniend.2013.07.001)

Bartolome JA, Thatcher WW, Melendez P, Risco CA \& Archbald LF 2005 Strategies for the diagnosis and treatment of ovarian cysts in dairy cattle. Journal of the American Veterinary Medical Association 227 1409-1414. (doi:10.2460/javma.2005.227.1409)

Bello NM, Steibel JP \& Pursley RP 2006 Optimizing ovulation to first GNRH improved outcomes to each hormonal injection of ovsynch in lactating dairy cows. Journal of Dairy Science 89 3413-3424. (doi:10.3168/jds. S0022-0302(06)72378-5)

Bigelow KL \& Fortune JE 1998 Characteristics of prolonged dominant versus control follicles: follicle cell numbers, steroidogenic capabilities, and messenger ribonucleic acid for steroidogenic enzymes. Biology of Reproduction 58 1241-1249. (doi:10.1095/biolreprod58.5.1241)

Borbolis F \& Syntichaki P 2015 Cytoplasmic mRNA turnover and ageing. Mechanism of Ageing and Development 152 32-42. (doi:10.1016/j. mad.2015.09.006)

Braw-Tal R \& Yossefi S 1997 Studies in vivo and in vitro on the initiation of follicle growth in the bovine ovary. Journal of Reproduction Fertility 109 165-171. (doi:10.1530/jrf.0.1090165)

Carroll DJ, Pierson RA, Hauser ER, Grummer RR \& Combs DK 1990 Variability of ovarian structures and plasma progesterone profiles in dairy cows with ovarian cysts. Theriogenology $34 \quad 349-370$. (doi:10.1016/0093-691X(90)90528-2)

Davis GH 2005 Major genes affecting ovulation rate in sheep. Genetics, selection, evolution 37 11-23. (doi:10.1186/1297-9686-37-S1-S11)

Díaz PU, Stangaferro ML, Gareis NC, Silvia WJ, Matiller V, Salvetti NR, Rey F, Barberis F, Cattaneo L \& Ortega HH 2015 Characterization of persistent follicles induced by prolonged treatment with progesterone in dairy cows: an experimental model for the study of ovarian follicular cysts. Theriogenology 84 1149-1160. (doi:10.1016/j. theriogenology.2015.06.015)

Dobson H, Ribadu AY, Noble KM, Tebble JE \& Ward WR 2000 Ultrasonography and hormone profiles of adrenocorticotrophic hormone (ACTH)-induced persistent ovarian follicles (cysts) in cattle. Journal of Reproduction and Fertility 120 405-410. (doi:10.1530/ jrf.0.1200405)

Erickson GF \& Shimasaki S 2003 The spatiotemporal expression pattern of the bone morphogenetic protein family in rat ovary cell types during the estrous cycle. Reproductive Biology and Endocrinology 19. (doi:10.1186/1477-7827-1-9)

Fatehi AN, van den Hurk R, Colenbrander B, Daemen AJ, van Tol HT, Monteiro RM, Roelen BA \& Bevers MM 2005 Expression of bone morphogenetic protein2 (BMP2), BMP4 and BMP receptors in the bovine ovary but absence of effects of BMP2 and BMP4 during IVM on bovine oocyte nuclear maturation and subsequent embryo development. Theriogenology 63 872-889. (doi:10.1016/j. theriogenology.2004.05.013)

Galloway SM, McNatty KP, Cambridge LM, Laitinen MP, Juengel JL, Jokiranta TS, McLaren RJ, Luiro K, Dodds KG, Montgomery GW et al. 2000 Mutations in an oocyte-derived growth factor gene (BMP15) cause increased ovulation rate and infertility in a dosagesensitive manner. Nature Genetics 25 279-283. (doi:10.1038/77033)

Glister C, Kemp CF \& Knight PG 2004 Bone morphogenetic protein (BMP) ligands and receptors in bovine ovarian follicle cells: actions of BMP-4, -6 and -7 on granulosa cells and differential modulation of Smad-1 phosphorylation by follistatin. Reproduction 127 239-254. (doi:10.1530/rep.1.00090)

Glister C, Richards SL \& Knight PG 2005 Bone morphogenetic proteins (BMP) $-4,-6$, and -7 potently suppress basal and luteinizing hormoneinduced androgen production by bovine theca interna cells in primary culture: could ovarian hyperandrogenic dysfunction be caused by a defect in thecal BMP signaling? Endocrinology 146 1883-1892. (doi:10.1210/en.2004-1303)

Glister C, Satchell L \& Knight PG 2010 Changes in expression of bone morphogenetic proteins (BMPs), their receptors and inhibin co-receptor betaglycan during bovine antral follicle development: inhibin can antagonize the suppressive effect of BMPs on thecal androgen production. Reproduction 140 699-712. (doi:10.1530/REP10-0216)

Glister C, Satchell L \& Knight PG 2011 Granulosal and thecal expression of bone morphogenetic protein- and activin-binding protein mRNA transcripts during bovine follicle development and factors modulating their expression in vitro. Reproduction 142 581-591. (doi:10.1530/REP11-0150)

Hatler TB, Hayes SH, Ray DL, Reames PS \& Silvia WJ 2008 Effect of subluteal concentrations of progesterone on luteinizing hormone and ovulation in lactating dairy cows. Veterinary Journal 177 360-368. (doi:10.1016/j.tvjl.2007.06.003)

Hosoya T, Otsuka F, Nakamura E, Terasaka T, Inagaki K, TsukamotoYamauchi N, Hara T, Toma K, Komatsubara M et al. 2015 Regulatory role of BMP-9 in steroidogenesis by rat ovarian granulosa cells. Journal of Steroid Biochemistry and Molecular Biology 147 85-91. (doi:10.1016/j. jsbmb.2014.12.007)

Inagaki K, Otsuka F, Miyoshi T, Yamashita M, Takahashi M, Goto J, Suzuki J \& Makino H 2009 p38-Mitogen-activated protein kinase stimulated steroidogenesis in granulosa cell-oocyte cocultures: role of bone morphogenetic proteins 2 and 4. Endocrinology 150 1921-1930. (doi:10.1210/en.2008-0851)

Isobe N \& Yoshimura Y 2007 Deficient proliferation and apoptosis in the granulosa and theca interna cells of the bovine cystic follicle. Journal of Reproduction and Development 53 1119-1124. (doi:10.1262/ jrd.19041)

Kayani AR, Glister C \& Knight PG 2009 Evidence for an inhibitory role of bone morphogenetic protein(s) in the follicular-luteal transition in cattle. Reproduction 137 67-78. (doi:10.1530/REP-08-0198)

Khalaf M, Morera J, Bourret A, Reznik Y, Denoual C, Herlicoviez M, Mittre H \& Benhaim A 2013 BMP system expression in GCs from polycystic ovary syndrome women and the in vitro effects of BMP4, BMP6, and BMP7 on GC steroidogenesis. European Journal of Endocrinology/European Federation of Endocrine Societies 168 437-444. (doi:10.1530/EJE-12-0891)

Knight PG \& Glister C 2006 TGF-beta superfamily members and ovarian follicle development. Reproduction 132 191-206. (doi:10.1530/ rep.1.01074)

Lagaly DV, Aad PY, Grado-Ahuir JA, Hulsey LB \& Spicer LJ 2008 Role of adiponectin in regulating ovarian theca and granulosa cell function. Molecular and Cellular Endocrinology 284 38-45. (doi:10.1016/j. mce.2008.01.007)

Liao WX, Moore RK, Otsuka F \& Shimasaki S 2003 Effect of intracellular interactions on the processing and secretion of bone morphogenetic protein-15 (BMP-15) and growth and differentiation factor-9. Implication of the aberrant ovarian phenotype of BMP-15 mutant sheep. Journal of Biological Chemistry 278 3713-3719. (doi:10.1074/jbc.M210598200)

Marelli BE, Díaz PU, Salvetti NR, Rey F \& Ortega HH 2014 Evaluation of gonadotropin receptors mRNA expression pattern in bovine follicular cysts. Reproductive Biology 14 276-281. (doi:10.1016/j. repbio.2014.08.002)

Matiller V, Stangaferro MS, Ortega HH, Díaz PU, Rey F, Huber E \& Salvetti NR 2014 Altered expression of transforming growth factor beta isoforms in bovine cystic ovarian disease. Reproduction in Domestic Animals 49 813-823. (doi:10.1111/rda.12373)

Mihm M \& Austin EJ 2002 The final stages of dominant follicle selection in cattle. Domestic Animal Endocrinology 23 155-166. (doi:10.1016/ S0739-7240(02)00153-4)

Ortega HH, Palomar MM, Acosta JC, Salvetti NR, Dallard BE, Lorente JA, Barbeito C \& Gimeno EJ 2008 Insulin-like growth factor I in ovarian follicles and follicular fluid from cows with spontaneous and induced Cystic Ovarian Disease. Research of Veterinary Science 84 419-427. (doi:10.1016/j.rvsc.2007.05.010)

Ortega HH, Salvetti NR \& Padmanabhan V 2009 Developmental programming: prenatal androgen excess disrupts ovarian steroid receptor balance. Reproduction 137 865-877. (doi:10.1530/REP-08-0491)

Ortega HH, Marelli BE, Rey F, Amweg AN, Díaz PU, Stangaferro ML \& Salvetti NR 2015 Molecular aspects of bovine cystic ovarian disease pathogenesis. Reproduction 149 R251-R264. (doi:10.1530/rep-14-0618)

Otsuka F 2013 Multifunctional bone morphogenetic protein system in endocrinology. Acta Medica Okayama 67 75-86.

Otsuka F, Yao Z, Lee T, Yamamoto S, Erickson GF \& Shimasaki S 2000 Bone morphogenetic protein-15: identification of target cells and 
biological functions. Journal of Biological Chemistry 275 39523-39528. (doi:10.1074/jbc.M007428200)

Otsuka F, Yamamoto S, Erickson GF \& Shimasaki S 2001 Bone morphogenetic protein-15 inhibits follicle-stimulating hormone (FSH) action by suppressing FSH receptor expression. Journal of Biological Chemistry 276 11387-11392. (doi:10.1074/jbc.M010043200)

Otsuka F, McTavish KJ \& Shimasaki S 2011 Integral role of GDF-9 and BMP-15 in ovarian function. Molecular Reproduction and Development 78 9-21. (doi:10.1002/mrd.v78.1)

Parrott JA \& Skinner MK 1997 Direct actions of kit-ligand on theca cell growth and differentiation during follicle development. Endocrinology 138 3819-3827. (doi:10.1210/endo.138.9.5368)

Peter AT 2004 An update on cystic ovarian degeneration in cattle. Reproduction in Domestic Animals 39 1-7. (doi:10.1046/j.09366768.2003.00466.x)

Pfaffl MW 2001 A new mathematical model for relative quantification in real-time RT-PCR. Nucleic Acids Research 29 45. (doi:10.1093/ nar/29.9.e45)

Pfaffl MW, Horgan GW \& Dempfle L 2002 Relative expression software tool (REST) for group-wise comparison and statistical analysis of relative expression results in real-time PCR. Nucleic Acids Research 3036. (doi:10.1093/nar/30.9.e36)

Pursley JR, Mee MO \& Wiltbank MC 1995 Synchronization of ovulation in dairy cows using PGF2 alpha and GNRH. Theriogenology 44 915-923. (doi:10.1016/0093-691X(95)00279-H)

Ranefall P, Wester K, Andersson AC, Busch C \& Bengtsson E 1998 Automatic quantification of immunohistochemically stained cell nuclei based on standard reference cells. Analytical Cellular Pathology 17 111-123. (doi:10.1155/1998/195432)

Rey F, Rodríguez FM, Salvetti NR, Palomar MM, Barbeito CG \& Ortega HH 2010 Role of the insulin-like growth factor-II and insulinlike growth factor binding proteins in bovine cystic ovarian disease. Journal of Comparative Pathology 142 193-204. (doi:10.1016/j. jcpa.2009.11.002)

Riollet C, Rainard P \& Poutrel B 2001 Cell subpopulations and cytokine expression in cow milk in response to chronic Staphylococcus aureus infection. Journal of Dairy Science 84 1077-1084. (doi:10.3168/jds. S0022-0302(01)74568-7)

Robinson T, Sutherland A \& Sutherland J 2007 Validation of candidate bovine reference genes for use with real-time PCR. Veterinary Immunology and Immunopathology 115 160-165. (doi:10.1016/j. vetimm.2006.09.012)

Rodríguez FM, Salvetti NR, Panzani CG, Barbeito CG, Ortega HH \& Rey F 2011 Influence of insulin-like growth factor-binding proteins- 2 and -3 in follicular cysts in bovine with cystic ovarian disease. Animal Reproduction Sciences 128 1-10. (doi:10.1016/j.anireprosci.2011.08.007)

Rodríguez FM, Salvetti NR, Colombero M, Stangaferro M, Barbeito CG, Ortega HH \& Rey F 2013 Interaction between IGF1 and IGFBPs in bovine cystic ovarian disease. Journal of Animal Science 140 14-25. (doi:10.1016/j.anireprosci.2013.04.012)

Rodríguez FM, Colombero M, Amweg AN, Huber E, Gareis NC, Salvetti NR, Ortega HH \& Rey F 2015 Involvement of PAPP-A and IGFR1 in cystic ovarian disease in cattle. Reproduction in Domestic Animals 50 659-668. (doi:10.1111/rda.12547)

Rossi RO, Costa JJ, Silva AW, Saraiva MV, Van den Hurk R \& Silva JR 2015 The bone morphogenetic protein system and the regulation of ovarian follicle development in mammals. Zygote 23 1-17. (doi:10.1017/ S0967199413000270)

Salvetti NR, Stangaferro ML, Palomar MM, Alfaro NS, Rey F, Gimeno EJ \& Ortega HH 2010 Cell proliferation and survival mechanisms underlying the abnormal persistence of follicular cysts in bovines with cystic ovarian disease induced by ACTH. Animal Reproduction Science 122 98-110. (doi:10.1016/j.anireprosci.2010.08.003)
Selvaraju S, Folger JK, Gupta PS, Ireland JJ \& Smith GW 2013 Stage-specific expression and effect of bone morphogenetic protein 2 on bovine granulosa cell estradiol production: regulation by cocaine and amphetamine regulated transcript. Domestic Animal Endocrinology $\mathbf{4 4}$ 115-120. (doi:10.1016/j.domaniend.2012.10.002)

Shimasaki S, Zachow RJ, Li D, Kim H, lemura S, Ueno N, Sampath K, Chang RJ \& Erickson GF 1999 A functional bone morphogenetic protein system in the ovary. PNAS 96 7282-7287. (doi:10.1073/ pnas.96.13.7282)

Shimasaki S, Moore RK, Otsuka F \& Erickson GF 2004 The bone morphogenetic protein system in mammalian reproduction. Endocrine Reviews 25 72-101. (doi:10.1210/er.2003-0007)

Shimizu T, Kayamori T, Murayama C \& Miyamoto A 2012 Bone morphogenetic protein (BMP)-4 and BMP-7 suppress granulosa cell apoptosis via different pathways: BMP-4 via PI3K/PDK-1/Akt and BMP-7 via PI3K/PDK-1/PKC. Biochemical and Biophysical Research Communications 417 869-873. (doi:10.1016/j.bbrc.2011.12.064)

Silvia WJ, Hatler TB, Nugent AM \& Laranja Da Fonseca LF 2002 Ovarian follicular cysts in dairy cows: an abnormality in folliculogenesis. Domestic Animal Endocrinology 23 167-177. (doi:10.1016/S07397240(02)00154-6)

Sirois J \& Fortune JE 1988 Ovarian follicular dynamics during the estrous cycle in heifers monitored by real-time ultrasonography. Biology of Reproduction 39 308-317. (doi:10.1095/biolreprod39.2.308)

Souza CJ, MacDougall C, Campbell BK, McNeilly AS \& Baird DT 2001 The Booroola (FecB) phenotype is associated with a mutation in the bone morphogenetic receptor type 1 B (BMPR1B) gene. Journal of Endocrinology 169 R1-R6. (doi:10.1677/joe.0.169R001)

Souza CJ, Campbell BK, McNeilly AS \& Baird DT 2002 Effect of bone morphogenetic protein 2 (BMP2) on oestradiol and inhibin A production by sheep granulosa cells, and localization of BMP receptors in the ovary by immunohistochemistry. Reproduction 123 363-369. (doi:10.1530/ rep.0.1230363)

Stangaferro ML, Matiller V, Díaz PU, Ortega HH, Rey F, Rodríguez FM, Silva MA \& Salvetti NR 2014 Role of activin, inhibin and follistatin in the pathogenesis of bovine cystic ovarian disease. Animal Reproduction Science 148 97-108. (doi:10.1016/j.anireprosci.2014.06.005)

Vanholder T, Opsomer G \& de kruif A 2006 A etiology and pathogenesis of cystic ovarian follicles in dairy cattle: a review. Reproduction Nutrition Development 46 105-119. (doi:10.1051/rnd:2006003)

Wilson T, Wu XY, Juengel JL, Ross IK, Lumsden JM, Lord EA, Dodds KG, Walling GA, McEwan JC, O'Connell AR et al. 2001 Highly prolific Booroola sheep have a mutation in the intracellular kinase domain of bone morphogenetic protein IB receptor (ALK-6) that is expressed in both oocytes and granulosa cells. Biology of Reproduction $\mathbf{6 4}$ 1225-1235. (doi:10.1095/biolreprod64.4.1225)

Yart L, Dessauge F, Finot L, Barbey S, Marnet PG \& Lollivier V 2012 Ovariectomy improves lactation persistency in dairy cows. Journal of Dairy Science 95 3794-3802. (doi:10.3168/jds.2011-5195)

Yoshioka K, Iwamura S \& Kamomae H 1996 Ultrasonic observations on the turnover of ovarian follicular cysts and associated changes of plasma LH, FSH, progesterone and estradiol-17 in cows. Research in Veterinary Science 61 240-244. (doi:10.1016/S00345288(96)90071-5)

Received 10 July 2015

First decision 14 August 2015

Revised manuscript received 27 June 2016

Accepted 1 August 2016 